\title{
Variscan ophiolites in NW Iberia: Tracking lost Paleozoic oceans and the assembly of Pangea
}

Departamento de Petrología y Geoquímica e Instituto de Geociencias (UCM, CSIC), Universidad Complutense, 28040 Madrid, Spain. E-mail: arenas@geo.ucm.es

DOI:10.18814/epiiugs/2015/v38i4/82427

In the Galicia Region of the NW Iberian Massif several allochthonous complexes (Cabo Ortegal, Órdenes and Malpica-Tui) contain a rootless Variscan suture that can be traced along the belt, from Iberia to the Bohemian Massif in Central Europe. Within these allochthonous complexes are several ophiolite zones bounded by two different continental terranes. There exist in NW Iberia two different ophiolite groups with different chemical compositions, isotopic signatures and structural positions. The Bazar and Vila de Cruces ophiolites, characterized by c. 500 Ma protolith ages, represent the Lower Group, whereas the Careon, Purrido and Moeche ophiolites containing 395 Ma maficultramafic sequences represent the Upper Group. This younger group constitutes the most widespread ophiolites in the Variscan Belt. A thick serpentinite mélange (Somozas Mélange) occurring at the base of the Cabo Ortegal Complex also belongs to the ophiolite zones of the Variscan suture. In this paper we describe the Galician ophiolites of the Variscan suture and discuss their tectonic setting of formation. We interpret the generation of the Galician ophiolites within the geodynamic and paleogeographic evolution of the Rheic Ocean and the Pangea supercontinent.

\section{Introduction}

In the Variscan Belt, a long suture zone is outlined by thick sequences of mafic and ultramafic rocks that are interpreted as ophiolites. These formed during the closure of at least one oceanic domain during the main stage of Pangea assembly. They are included in allochthonous complexes of several exotic terranes that were, in some cases, affected by high pressure metamorphic events (Martínez Catalán et al., 2007; Fig. 1). It is accepted that the Rheic Ocean was the main oceanic domain closed during the collision of Gondwana and Laurussia in Late Devonian and Carboniferous times (Matte,
2001; Stampfli and Borel, 2002; Winchester et al., 2002) but other, minor, oceanic domains also participated in the formation of Pangea (Arenas et al., 2014a). The Rheic Ocean was the largest ocean during the Paleozoic, in Middle Cambrian-Early Ordovician times, formed during the rifting and later drifting of Avalonia and other minor terranes away from Gondwana (Murphy et al., 2006; Nance et al., 2010; van Staal et al., 2012).

Several recent papers have described the lithologies, chemical compositions and isotopic geochronology of the ophiolites of NW Iberia (Arenas et al., 2007a; Sánchez Martínez et al., 2009). It is now well-known that their igneous protoliths correspond to two age groups which cannot be linked to one stage in the evolution of a single oceanic domain. These ophiolites provide information about the oceanic domains located along the periphery of Gondwana in pre-Ordovician times as well as the oceanic domains involved in the final assembly of Pangea. Two groups of ophiolites can be distinguished: an older group containing Cambrian meta-igneous rocks while a second younger group includes Devonian gabbroic rocks. Moreover, a thick serpentinite mélange forms part of these groups of mafic-ultramafic units.

The long Variscan-Appalachian-Alleghenian Orogen, which extends through parts of Europe and eastern North America, contains key information for reconstructing the amalgamation history of the Pangea supercontinent. In the Variscan Belt, the oldest tectono-thermal events are preserved in the complex suture zone that can be traced from the Iberian Peninsula to the Bohemian Massif (Fig. 1). Two different events of high pressure metamorphism appear to have occurred, relatively close in time although separated by the development of oceanic basins. This evolution is unusual in large collisional belts in which tectono-thermal evolution is commonly interpreted as reflecting a single high-P (HP) or ultra-high-P (UHP) metamorphic event associated with subduction of one of the colliding continental margins (Platt, 1986; Beaumont et al., 2009). In the Variscan Belt, both HP events and the development of some of the oceanic domains occurred after the earliest Devonian and are thus broadly coeval with the initial stages of the assembly of Pangea.

This paper presents a short overview of the features and origin of the ophiolites along the Variscan suture of NW Iberia, and provides a conceptual model within the context of Pangea assembly. These ophiolites are interpreted in relation to the origin and tectonothermal evolution of the other allochthonous terranes in the region. The geological section exposed in the NW Iberian Massif is taken as an example, but allochthonous terranes are fairly continuous along 


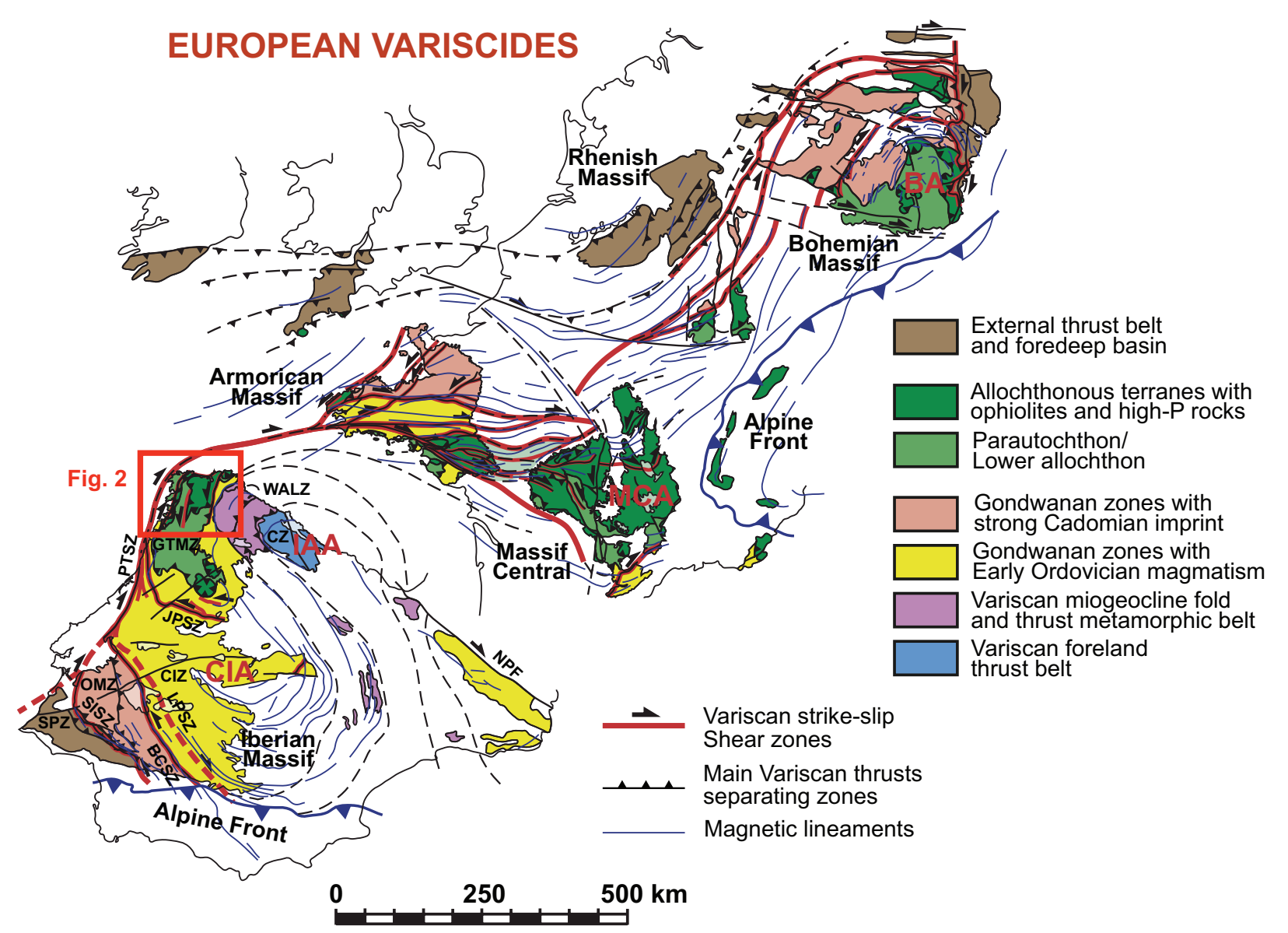

Fig.1. Terranes and oroclines of the Variscan belt (Martínez Catalán, 2011). Arcs: BA, Bohemian; CIA, Central Iberian; IAA, IberoArmorican; MCA, Massif Central. Zones of the Iberian Massif: CIZ, Central Iberian; CZ, Cantabrian; GTMZ, Galicia-Trás-os-Montes; OMZ, Ossa-Morena; SPZ, South Portuguese; WALZ, West Asturian-Leonese. Shear zones and faults: BCSZ, Badajoz-Córdoba; JPSZ, Juzbado-Penalva; LPSZ, Los Pedroches; NPF, North Pyrenean; PTSZ, Porto-Tomar; SISZ, Southern Iberian. Location of the geological map and section presented in Fig. 2 is also shown.

the suture and are largely comparable throughout the European Variscan Belt (Faryad and Kachlik, 2013; Kroner and Romer, 2013; Ballèvre et al., 2014; Von Raumer et al., 2015). Recent isotopic and geochronological data on the origin of these ophiolites and $\mathrm{U}-\mathrm{Pb}$ geochronological constraints on the HP events provide new insights into the early events involved in the formation of Pangea. We infer that the history of convergence and collision was probably longer and more complex than previously described, and that the origin and evolution of the most common ophiolites in the Variscan belt were related to the amalgamation of the supercontinent Pangea.

\section{Terranes incorporated into the Variscan suture of NW Iberia}

The NW Iberian section of the Variscan Belt contains terranes with contrasting origins and tectono-thermal evolutions (Arenas et al., 1986; Martínez Catalán et al., 2009). The Central Iberian Zone is the lowest sequence and, together with a parautochthonous domain (Parautochthon or Schistose Domain), defines the main section of the Gondwanan margin involved in the Variscan Orogen (Martínez Catalán et al., 2009) (Figs. 1 and 2). Above that sequence, a set of terranes of allochthonous and alleged exotic origin forms a nappe stack representating the rootless suture zone (Figs. 1 and 2). The origins of the allochthonous complexes have been extensively discussed (Martínez Catalán et al., 2009). Three main groups of terranes have been identified, two of which show continental crustal affinities (Basal and Upper Units). These are separated by ophiolites representing the suture itself (ophiolitic units; Fig. 2).

Located immediately below the suture, the Basal Units contain metasedimentary rocks (comprised of a thick pile of metagreywackes with minor metapelites, graphitic schist, calc-silicate lenses, metacherts and quartzites), calc-alkaline to alkaline-peralkaline metagranitoids, and some mafic rocks. Maximum depositional ages for the metasedimentary series range between Ediacaran and Early Ordovician (Díez Fernández et al., 2010, 2012a) with Nd model ages of between 1.78 and 2.22 Ga (Fuenlabrada et al., 2012). Major and trace element geochemistry of the metagreywackes suggests deposition in association with a peri-Gondwanan arc system built upon a thinned continental margin. Calc-alkaline (c. $493 \mathrm{Ma}$; Abati et al., 2010) and alkaline-peralkaline (c. 475-470 Ma; Díez Fernández et al., 2012b) granitoids were generated within this arc, suggesting a change over time from convergence to continental rifting. The Basal Units are considered to represent a section of the most external margin of Gondwana originally located somewhere between the West African and Saharan cratons (Díez Fernández et al., 2010). The first tectonothermal event recorded in these units is a HP and low- to intermediate- 
T (LIT) event dated at c. 370 Ma (Rodríguez et al., 2003; Abati et al., 2010). A variety of HP mica schists and orthogneisses, C-type eclogites (Coleman et al., 1965) and some blueschists were formed at that time (Arenas et al., 1995, 1997; Rodríguez et al., 2003; López Carmona et al., 2013, 2014).

Resting above this suture zone, the Upper Units consist of a 10$12 \mathrm{~km}$ thick pile of: metasedimentary rocks (mainly metagreywackes) and large massifs of calc-alkaline orthogneisses, and gabbros, with compositions of island-arc tholeiites, together with medium to highgrade mafic rocks, including B-type eclogites (Coleman et al., 1965), HP granulites, and some ultramafic massifs. The structurally highest low grade metagreywackes have a Middle Cambrian maximum depositional age (Fernández-Suárez et al., 2003), with Nd model ages ranging between 0.72 and $1.22 \mathrm{Ga}$, and major and trace element compositions typical of active margin settings (Fuenlabrada et al., 2010). Protolith ages for the gabbros and granitoids range between 490 and 520 Ma (Fernández-Suárez et al., 2007; Andonaegui et al., 2012). These units were probably part of a Cambrian peri-Gondwanan magmatic arc located in the periphery of the West African Craton, to the West of the external margin section represented by the Basal Units (Díez Fernández et al., 2010; Fuenlabrada et al., 2010; Albert et al., 2015). The Upper Units may be divided into two groups based on metamorphic criteria. An uppermost section shows intermediate-P (IP) metamorphism ranging from chlorite to granulite facies. The main tectono-thermal events recorded in this uppermost section are Cambrian in age and were probably developed in response to the accretionary dynamics of the peri-Gondwanan arc system (Abati et al., 1999, 2007; Díaz García et al., 2010). A lower section is characterized by HP and high-T (HT) metamorphism dated at c. 400390 Ma (Ordóñez Casado et al., 2001; Fernández-Suárez et al., 2007). The latter metamorphic event reached UHP conditions in other domains of the Variscan belt (Lardeaux et al., 2001).

The ophiolites of NW Iberia consist of a diverse group of maficultramafic sequence making up five different ophiolites and a serpentinite mélange (Fig. 2). Two groups of ophiolitic units have been distinguished (Fig. 2): an older group (Lower Ophiolitic Units) containing meta-igneous rocks of Late Cambrian age (c. 497-495 Ma), and a younger group (Upper Ophiolitic Units) including gabbroic rocks of Devonian age (Emsian-Eifelian; c. $395 \mathrm{Ma}$ ). The Lower Ophiolitic Units are interpreted as a series of mafic complexes linked to the dynamics affecting the most external margin of Gondwana in Cambrian-Early Ordovician times. The Middle Devonian ophiolites are the most abundant group found in the Variscan suture (Díaz García et al., 1999; Murphy et al., 2011; Arenas et al., 2014b). The origin of this group of ophiolites has been the subject of different interpretations. The most relevant features of the Galician ophiolites are described in the following sections.

\section{Ophiolitic units}

According to a typical Wilson Cycle, a collisional orogen should contain a single ophiolitic belt, representative of the consumed oceanic domain. However, it is known that preservation of ancient N-MORB type oceanic lithosphere is extremely difficult, since its thermal structure favors complete elimination by subduction. In contrast, many of the ophiolites emplaced in orogenic belts are sequences typically generated in supra-subduction zone settings, either during the last stages of the closure of the ocean or during the opening of more-orless ephemeral basins (Leitch, 1984; Pearce et al., 1984; Dilek and
Furnes, 2011). Ophiolitic belts generated in connection with pullapart ephemeral basins have also been described (Murphy et al., 2011). These buoyant oceanic lithospheres show greater resistance to subduction and can be easily thrust over continental margins instead (Murphy et al., 2011). Moreover, the dynamics of the collision and the eventual development of a high rate of lateral convergence may allow the incorporation of oceanic sections of different ages and characteristics into the orogen. Hence, the real dynamic context may generate situations that tend to increase the variety of ophiolitic belts incorporated into an orogen which rarely contains a simple ophiolite generated at one particular time. In the Variscan Belt recent studies have described a variety of ophiolites with significant differences in lithological constitution and age. Such diversity responds to a variety of dynamic settings of generation. Proper understanding of these would improve knowledge of paleogeographic evolution in preVariscan and Variscan times.

In the NW Iberian Massif, a set of tectono-stratigraphic units comprising mafic and ultramafic lithologies, and almost devoid of metasedimentary rocks, were interpreted as ophiolites included in the allochthonous complexes (Arenas et al., 1986). Two groups of ophiolitic units are distinguished in Galicia (Arenas et al., 2007a) (Fig. 2), which can be generally correlated with equivalent groups along the entire belt. The Upper Ophiolitic Units are Devonian in age and according to their chronology they represent the most common type of ophiolites in the Variscan suture (Díaz García et al., 1999; Murphy et al., 2011; Arenas et al., 2014b). Ophiolites of this age have also been described in Cornwall (Lizard Ophiolite; Clark et al., 1998; Nutman et al., 2001), Armorican Massif (Drain Ophiolite; Ballèvre et al., 2009, 2014) and the Bohemian Massif (Sleza Ophiolite; Dubinska et al. 2004; Kryza and Pin 2010). These ophiolites have been traditionally considered to be related to the evolution of the Rheic Ocean, their origin coinciding with the final stages of its development (Díaz García et al., 1999; Sánchez Martínez et al., 2007a). However, new geochronology and isotope geochemistry data question the relationship of the Devonian ophiolites with this ocean, suggesting that they are more likely to be related to the opening of minor ephemeral oceanic domains (Arenas et al., 2014a). The Lower Ophiolitic Units include Cambrian mafic-ultramafic sequences which developed in different dynamic contexts. Their origin may be related either to the opening of the Rheic Ocean (Arenas et al., 2007b) or to a geodynamic regime that occurred prior to the opening of this ocean (Sánchez Martínez et al., 2012).

In the NW Iberian Massif in Galicia, five ophiolitic units have been delineated. The Lower Ophiolitic Units comprise the Vila de Cruces and Bazar ophiolites while the Upper Ophiolitic Units are represented by the Careón, Purrido and Moeche ophiolites. A thick mélange of serpentinite, the Somozas Mélange, can be included among the ophiolitic and related sequences of NW Iberian Massif.. Other different ophiolitic units of similar age and setting have also been described in the neighboring region of Trás-os-Montes, Portugal (Pin et al., 2006). The ophiolitic units of Galicia will be described separately, as they show different lithologic constitutions and tectonothermal evolutions.

\section{Lower Ophiolitic Units}

\section{Bazar Ophiolite}

The Bazar Ophiolite, located in the westernmost part of the 
(b)

(a)

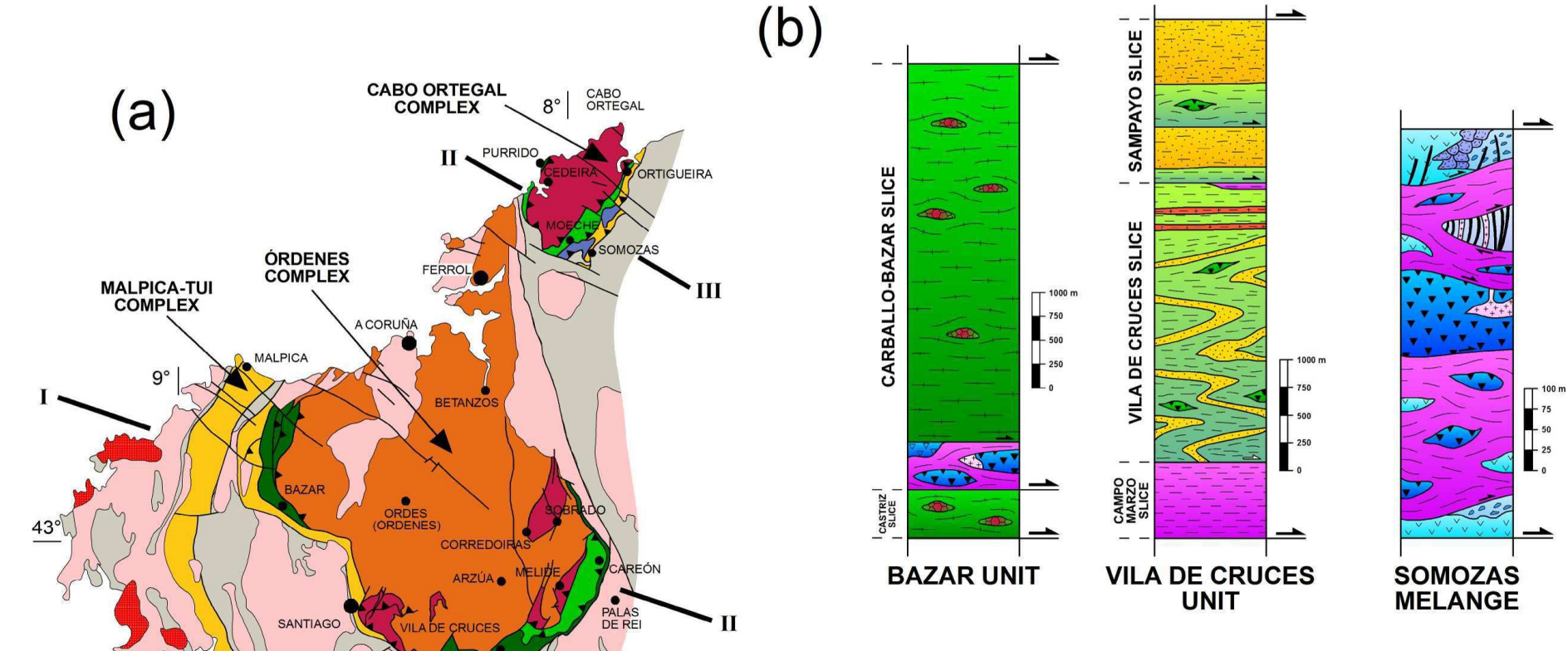

\section{UPPER OPHIOLITES}

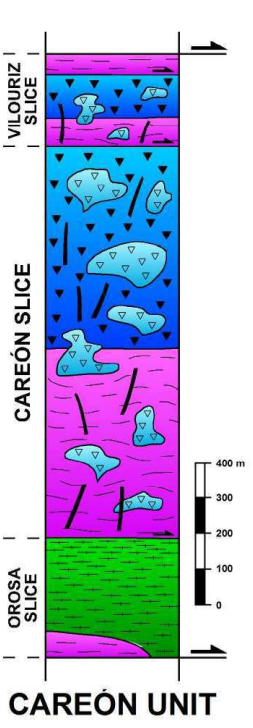

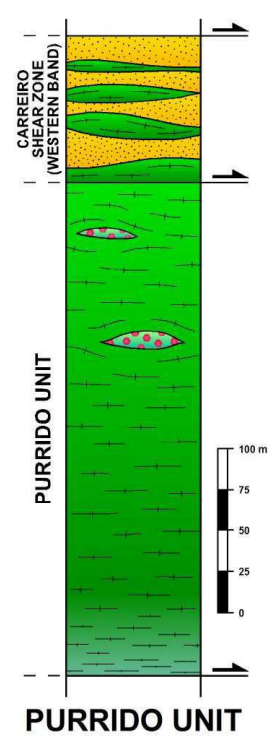

\section{LITHOLOGIES}

Phyllites and micaschists

Greenschists and mylonitic greenschists

13 Broken

20 pillow breccias

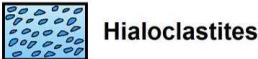

Metavolcanic rocks (basalts

atic andesites)

腈国 Dykes of diabases and

Amphibolites

3 Ca-poor amphibolites

Ca-poor amphinolles
(garnet enriched levels)

Mafic granulites within

HT amphibolites

$\because \forall$ Metagabbros

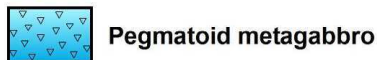

Granitic orthogneiss

Granitoids

Ultramafic rocks

(serpentinites)

」 Diabase dyke

Fig.2. (a) Geological map and cross section of the allochthonous complexes of the NW Iberian Massif (Galicia region). These show the distribution and general structure of the terrane involved in the Variscan suture. The locations and names of the ophiolites are also indicated. (b) Schematic columns showing the lithological constitution of the ophiolites from Galicia. 
Órdenes Complex (Fig. 2), consists of an imbricate of tectonic slices, c. $5000 \mathrm{~m}$ thick, containing metagabbroic rocks and a minor proportion of ultramafic rocks at the base of the ophiolite (Díaz García, 1990). The main tectonic slice (Carballo-Bazar; Sánchez Martínez et al., 2009, 2012; Fig. 2) is c. $4000 \mathrm{~m}$ thick and is composed of amphibolites and foliated metagabbros with an HT foliation, which evolved from an initial granulite-facies tectono-thermal event (Fig. 3). Scarce metresized boudins of mafic granoblastic granulites are preserved within the metagabbros (Fig. 3). They are wrapped by the HT foliation and their mineral association is transitional between low and intermediate pressure conditions (plagioclase-clinopyroxene-orthopyroxenehornblende-ilmenite \pm garnet \pm olivine). The lower part of the main slice consists of relatively well-preserved gabbros and ultramafic rocks, with minor leucogabbros and tonalites (Fig. 2). The geochemical features of the most representative lithologies of the Bazar Ophiolite are variable. The common amphibolites, which are the most abundant lithological type, and the metagabbros, show compositions equivalent to island-arc tholeiites or N-MORB (Fig. 4a). However, the mafic granulites seem to be transitional between MOR (mid-ocean ridge) and WP (within-plate) basalts, with normalized trace element patterns similar to those of T-MORB generated by plume-ridge interactions (Pearce, 1996) (Fig. 4a).

Zircon grains obtained from an amphibolite sample have an internal structure characterized by the presence of a magmatic core surrounded by a very irregular overgrowth rim (Fig. 5a). Their analysis yielded two different groups of U-Pb concordant ages (Fig. 5b) which are significant according to their contrasting ${ }^{176} \mathrm{Yb} /{ }^{177} \mathrm{Hf}$ ratios (Fig. $5 \mathrm{c})$. The first group corresponds to an average age of $495 \pm 2 \mathrm{Ma}$ interpreted as the intrusive age of the gabbroic protoliths. The second group yields an average age of $475 \pm 2 \mathrm{Ma}$ and is interpreted to date the high-T metamorphic event (Sánchez Martínez et al., 2012). The Hf isotope composition of the zircons from this amphibolite sample reveals the juvenile signature of the mafic protoliths of this unit and a lack of interaction with old crustal components (Fig. 5d). These features, combined with the trace element composition of the mafic rocks, suggest that the protoliths of the Bazar Ophiolite were generated in an oceanic setting, although the mafic rocks are compositionally heterogeneous.

The compositional features, age and tectono-thermal evolution of the Bazar Ophiolite indicate that it may represent a lithospheric section of the Cambrian peri-Gondwanan ocean. The specific dynamic setting in which the mafic rocks originated is uncertain, but the presence of metagabbros with N-MORB composition suggests that it involved the participation of a mid-ocean ridge. The oceanic lithosphere represented by the Bazar Ophiolite should have been buoyant, given the small time difference (c. $20 \mathrm{Ma}$ ) between the ages of protoliths and HT metamorphism, and was accreted under the peri-Gondwana system of magmatic arcs. The development of a lowmedium-P granulitic metamorphism is compatible with overheating associated with the base of the magmatic arc, but could also be caused
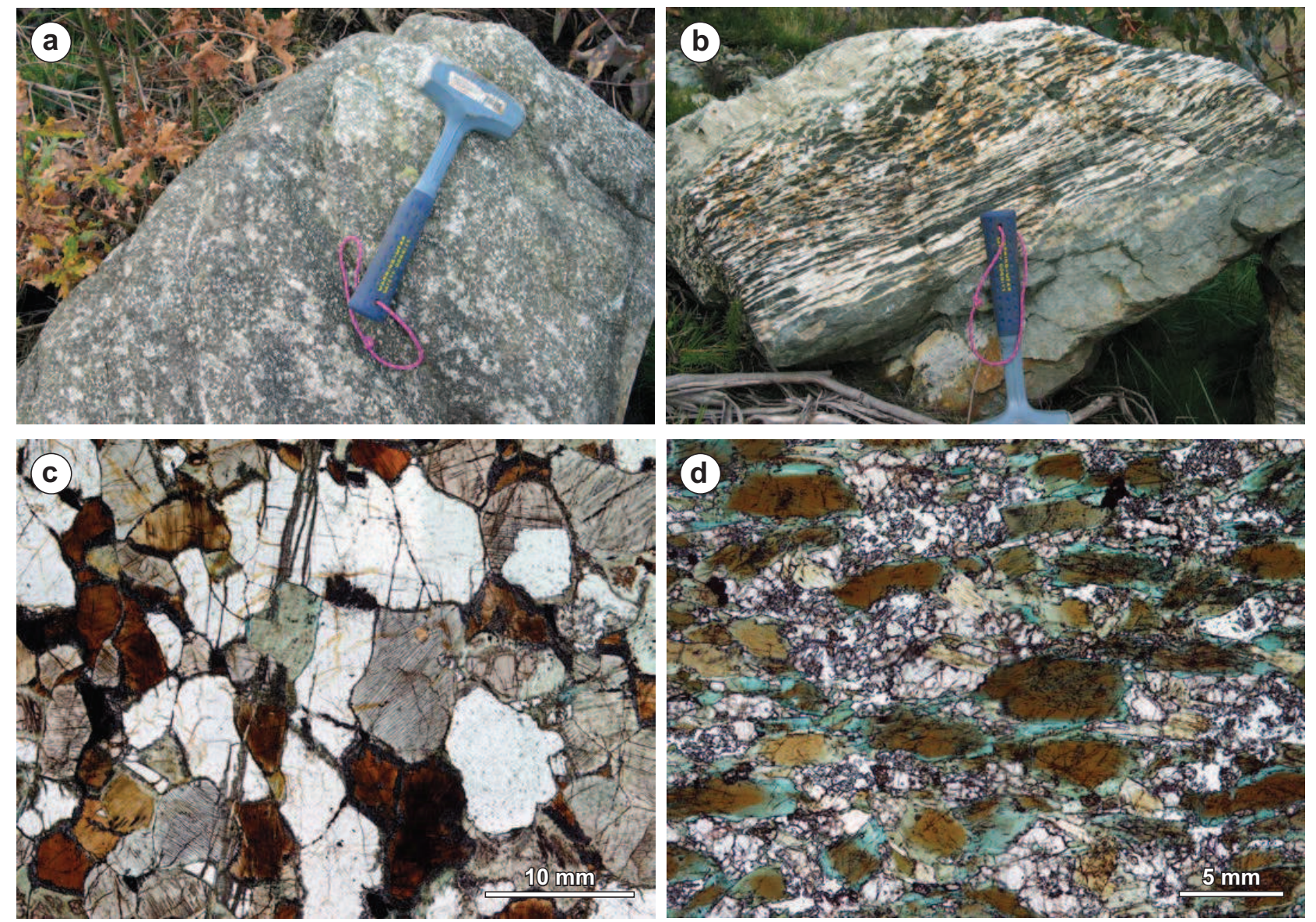

Fig. 3. Field and petrographic aspects of the Bazar Ophiolite. (a) Coarse-grained gabbro. (b) Strongly sheared metagabbro. (c) Low to intermediate-P mafic granulite composed of clinopyroxene, orthopyroxene, plagioclase, brown hornblende, biotite and very thin garnet coronas, occasional olivine crystals can also appear. (d) HT amphibolite developed after the granulites. It shows a first generation of brown hornblende subsequently replaced by blue-green amphibole. 


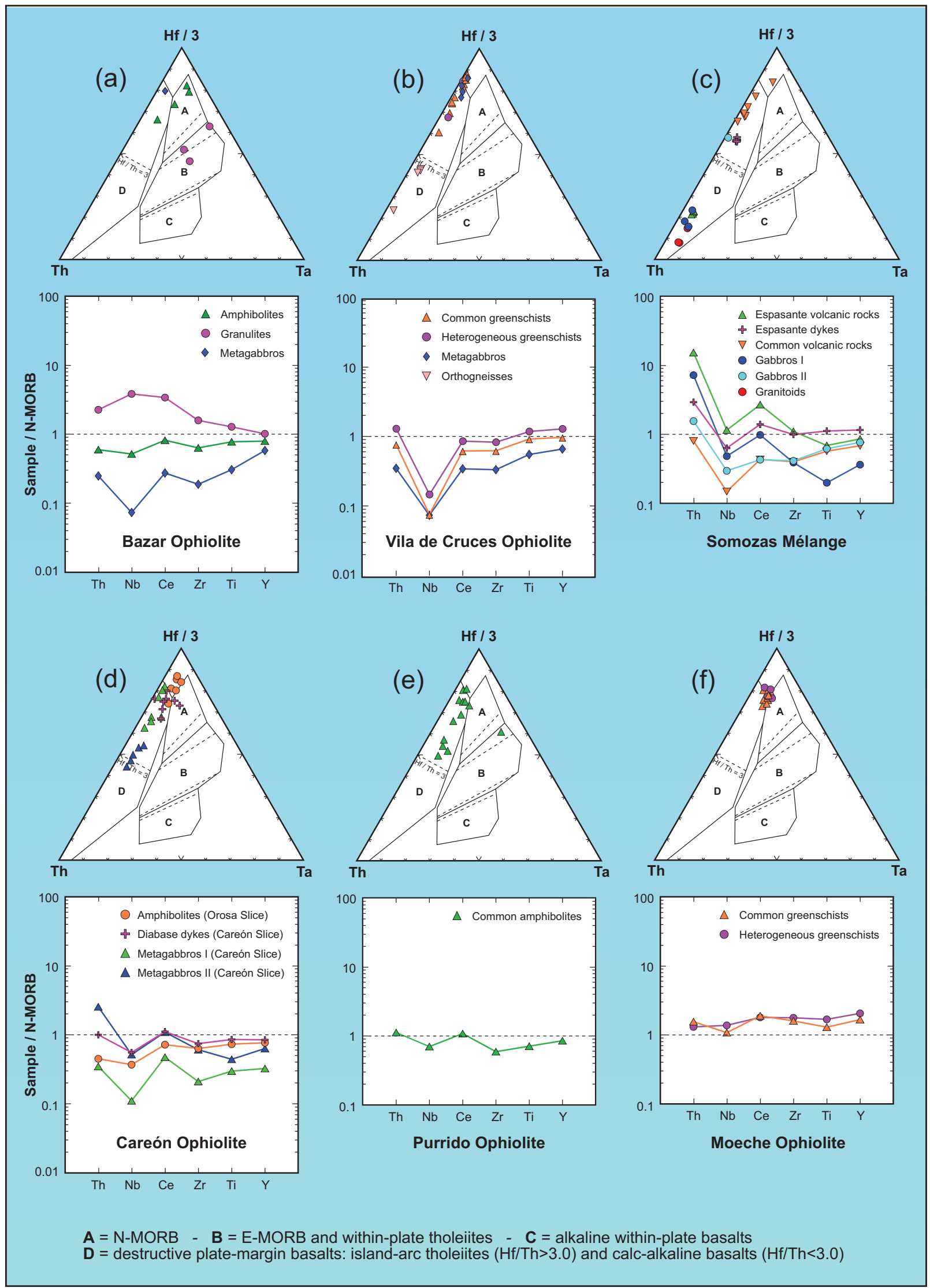

Fig. 4. Th-Hf-Ta diagrams (Wood, 1980) and N-MORB-normalized trace-element patterns (selected elements and normalizing values according to the criteria of Pearce, 1996) for the most representative lithologies of the ophiolites included in the allochthonous complexes of Galicia. (a) Bazar Ophiolite. (b) Vila de Cruces Ophiolite. (c) Somozas Mélange. (d) Careón Ophiolite. (e) Purrido Ophiolite. (f) Moeche Ophiolite. 


\section{(a)}
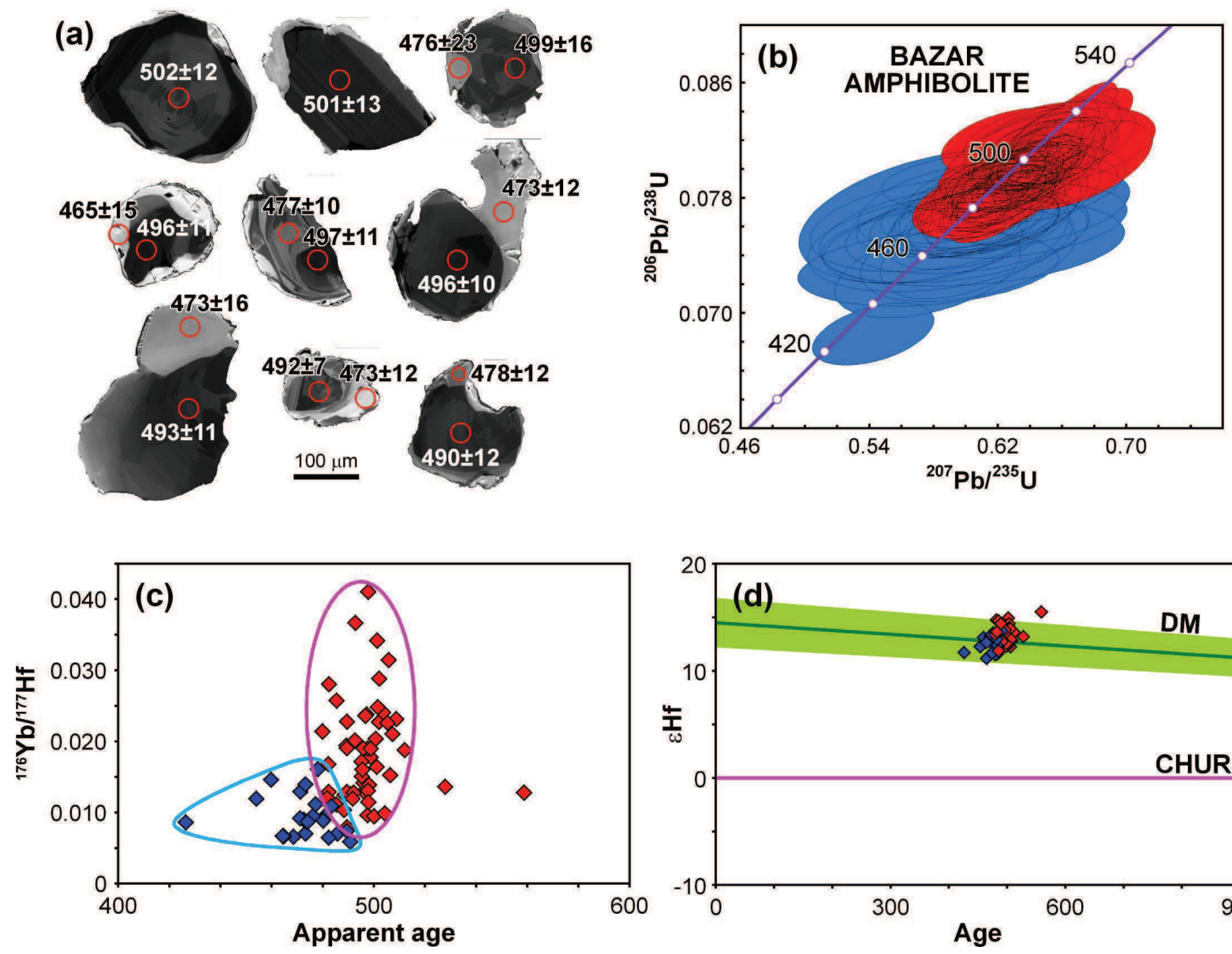

Fig. 5. U-Pb dating and Lu-Yb-Hf isotope data of a metagabbroic amphibolite sample from the Bazar Ophiolite. (a) Cathodo-luminiscence images of selected zircons, circles representing the spot size of U-Th-Pb analyses. (b) Concordia diagram showing the results of the $U$-Pb analyses, with two statistically coherent groups of data. (c) ${ }^{176} \mathrm{Yb} /{ }^{177} \mathrm{Hf}$ versus apparent age diagram, the different trends of each group of analyses appearing encircled. (d) EHf versus apparent age plot; the depleted mantle array $(D M)$ is extrapolated from average modern-day values of mid-ocean ridge basalts (Chauvel and Blichert-Toft, 2001), assuming a linear behaviour from $\mathrm{EHf}=2$ at $4000 \mathrm{Ma}$ (Vervoort and Blichert-Toft, 1999). Red symbols = zircon cores, blue symbols = zircon overgrowths-recrystallized domains. Modified after Sánchez Martínez et al. (2012).

by the subduction of a section of a mid-ocean ridge and the opening of an ephemeral asthenospheric window (Fig. 6).

\section{Vila de Cruces Ophiolite}

Located SE of the Órdenes Complex, the Vila de Cruces Ophiolite has a complex structure characterized by the presence of at least two superimposed tectonic slices with a total thickness of c. $4000 \mathrm{~m}$ (Fig. 2). The main lithologies are greenschist rocks of possible metavolcanic origin, alternating with abundant layers of phyllites, mica schists and schists with albite and garnet porphyroblasts, and scarce metachert bands. Lenticular intercalations of metagabbros and two bodies of tonalitic orthogneisses, transitional to metagabbroic types, can also be identified. Thin serpentinite bands occur along the contact between the main slices. Immobile trace element abundances of both the mafic types and the tonalitic orthogneisses are typical of magmas generated at destructive plate margins (Fig. 4b). Greenschists and metagabbros have compositions characteristic of island-arc tholeiites. The presence of a strong negative $\mathrm{Nb}$ anomaly compared to N-MORB (Fig. 4b) is also compatible with the supra-subduction zone setting proposed for this ophiolite (Arenas et al., 2007b).

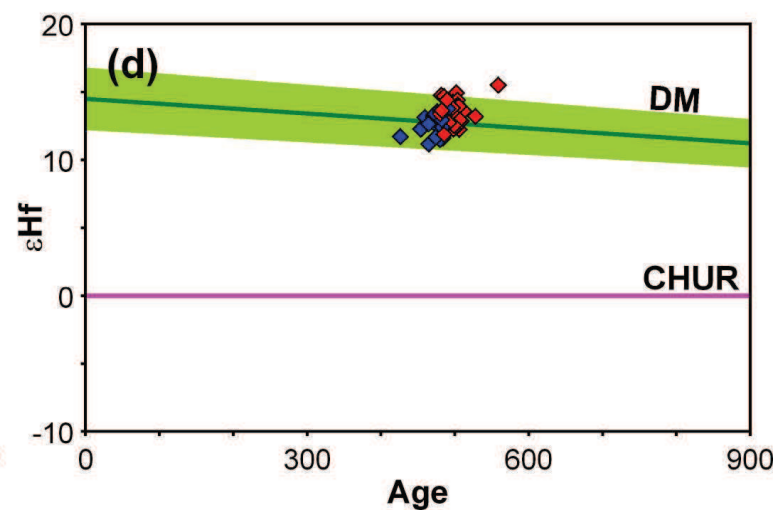

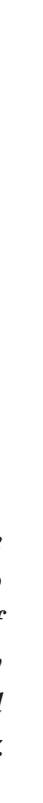




\section{CAMBRO - ORDOVICIAN $(500-480 \mathrm{Ma})$}

\begin{tabular}{ll}
\hline & CONTINENTS \\
& $\begin{array}{l}\text { FUTURE BASAL UNITS AND } \\
\text { AUTOCHTHONUS SERIES }\end{array}$ \\
& FUTURE UPPER UNITS \\
\hline & OCEANS \\
\hline & LITHOSPHERIC MANTLE \\
\hline & ASTHENOSPHERIC MANTLE
\end{tabular}
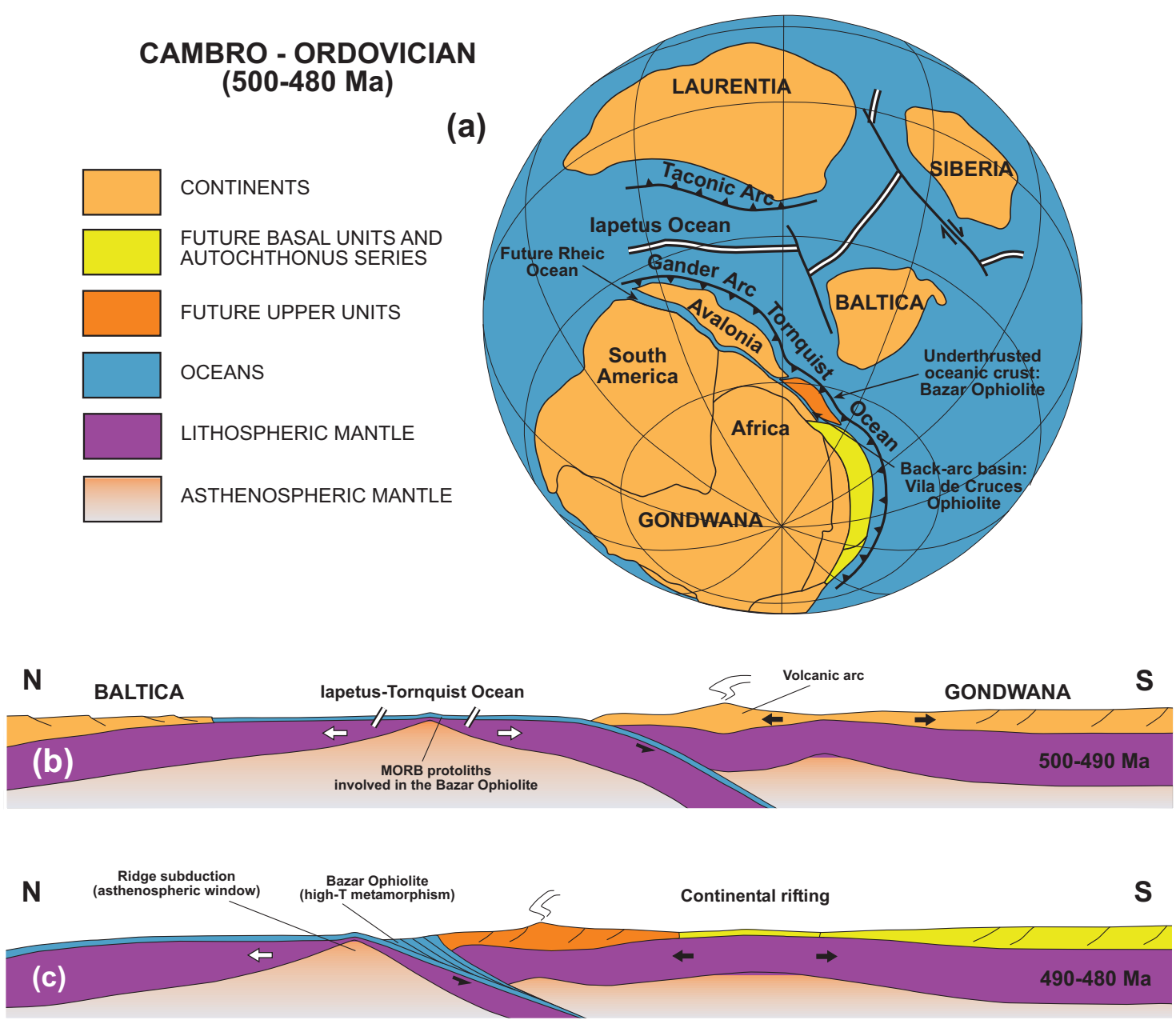

Fig. 6. A paleogeographic reconstruction (a) and interpretive tectonic cross sections of the Iapetus realm during the Cambro-Ordovician (b and c). These diagrams show the tectonic setting for a time immediately prior to the opening of the Rheic Ocean. The Bazar Ophiolite probably represents a remnant of the peri-Gondwanan oceanic lithosphere accreted below a volcanic-arc system, whereas the Vila de Cruces Ophiolite contains the remnants of an incipient backarc basin. Based on Winchester et al. (2002), Arenas et al. (2007b), Gómez Barreiro et al. (2007) and Sánchez Martínez et al. (2012).

an initial HP metamorphic event. The age of the regional foliation is estimated at 363-367 Ma, according to ${ }^{40} \mathrm{Ar}{ }^{39} \mathrm{Ar}$ dating of white mica concentrates from two phyllite samples (Dallmeyer et al., 1997).

Because the chemical composition of the mafic and felsic rocks is typical of magmatic arcs, and the abundance of sedimentary rocks, the Vila de Cruces Ophiolite is considered to be a supra-subduction zone sequence generated in a Cambrian back-arc basin opened at the periphery of Gondwana (Arenas et al., 2007b) (Fig. 6). It therefore represents a transitional crust domain where magmas of juvenile mantle provenance interacted with a thinned continental crust.

\section{Upper Ophiolitic Units}

\section{Careón Ophiolite}

This ophiolitic unit contains the best preserved meta-igneous succession in the NW Iberian Massif (Fig. 2). It consists of three imbricated sheets that repeat the mantle-crust transition with a total thickness of c. $1500 \mathrm{~m}$ (Figs. 7 and 8). The thickest slice is the c. $1000 \mathrm{~m}$ thick Careón Sheet, which consists mainly of serpentinized ultramafic rocks and isotropic metagabbros, with abundant stocks of pegmatoid metagabbros emplaced at all levels as well as scarce wehrlite sills. Diabase and late diabase dykes cut all exposed levels, from the deepest mantle section to the most superficial crustal sections.

The lithological constitution of the Careón Ophiolite differs significantly from the classical HOT and LOT ophiolitic types defined by Nicolas $(1989,1995)$ (Fig. 8). Therefore, it was interpreted as an ophiolite generated in a supra-subduction zone setting by Díaz García et al. (1999). The intrusion of abundant diabase dikes at all levels of the Careón Sheet suggests the development of this ophiolite via extension and thinning, in the upper plate of a subduction zone. Immobile trace element abundances (Wood, 1980) (Fig. 4d) are typical of island-arc tholeiitites, and the youngest diabase dykes have compositions transitional to N-MORB. All lithologies present in the Careón Ophiolite display a negative $\mathrm{Nb}$ anomaly compared to N-MORB, which is compatible with generation in an active supra-subduction zone setting (Sánchez Martínez et al., 2007a) (Fig. 4d).

The Careón Ophiolite was the first ophiolite to be dated by isotope geochronology in the NW Iberian Massif. U-Pb zircon dating of a sample of pegmatoid metagabbro from the Careón Sheet yielded a 

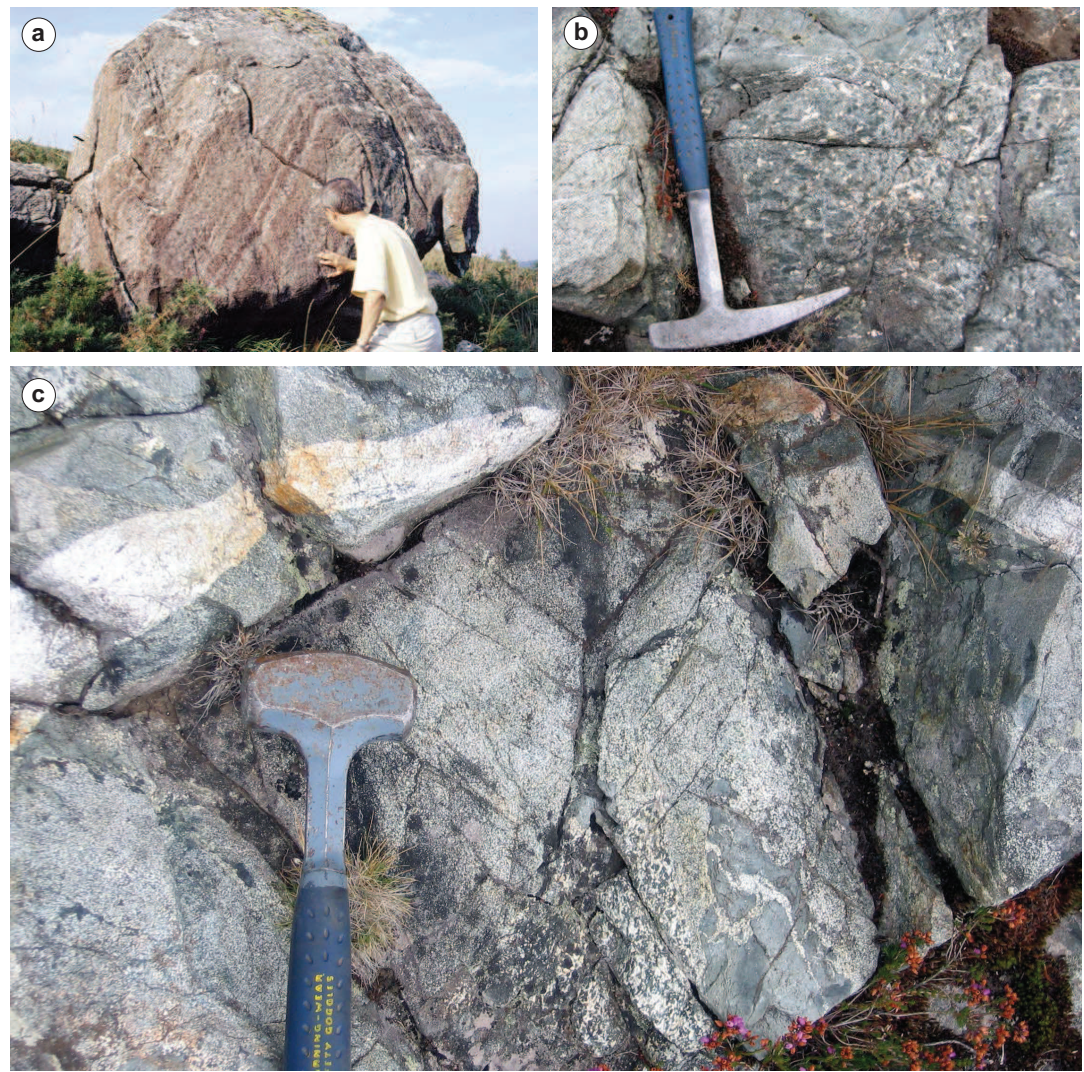

Fig. 7. Field aspects of the Careón Ophiolite. (a) Layered ultramafic rocks. (b, c) Complex intrusive relationships with local development of mingling processes.

\section{Purrido Ophiolite}

Located at the westernmost limit of the Cabo Ortegal Complex, the Purrido Ophiolite consists of c. $300 \mathrm{~m}$ of monotonous amphibolites and garnet-bearing amphibolites of metagabbroic origin (Figs. 2 and 9). Unlike the Careón Ophiolite, well preserved igneous features are not seen but the amphibolite types that appear within both units are very similar from mineralogical and compositional points of view, so both of these ophiolites have been traditionally correlated (Sánchez Martínez et al., 2007b). The mafic rocks have compositions typical of island-arc tholeiites, with slight negative $\mathrm{Nb}$ anomalies (Sánchez Martínez et al., 2007b) (Fig. 4e).

$\mathrm{U}-\mathrm{Pb}$ dating of an amphibolite with a dominant zircon population of c. $1160 \mathrm{Ma}$ was originally interpreted as the age of the gabbroic protolith but with minor populations ranging between $1.2-1.6 \mathrm{Ga}$ considered to be inherited grains (Sánchez Martínez et al., 2006). However, subsequent U-Pb zircon dating of two amphibolite samples provided a single consistent age at c. $395 \mathrm{Ma}$, interpreted as the actual protolith age thus coinciding with the age previously obtained in the Careón Ophiolite (Sánchez Martínez et al., 2011). The Lu-Hf isotope geochemistry in zircons from this ophiolite demonstrate complex evolution, clearly indicating participation of PaleoProterozoic isotopic sources and mixing with juvenile material at c. $395 \mathrm{Ma}$ (Fig. 10). Whole rock Sm-Nd

protolith age of c. 395 Ma (Díaz García et al., 1999). Similar U-Pb ages were obtained later by analyzing zircons from a similar metagabbro sample from the same sheet (Pin et al., 2002). The three imbricated sheets have a penetrative foliation with evidence of increasing temperature towards the top of each sheet, reaching the highest temperatures close to the contact with the ultramafic rocks of each overlying sheet. There, the gabbroic rocks were transformed into garnet amphibolites. There are also higher temperature metamorphic soles with very local development of metre-scale corundum-rich layers (Fig. 8). The P-T conditions reached during the deep imbrication of the ophiolitic sheets are estimated as 11.5 Kbar and $650{ }^{\circ} \mathrm{C}$ in the garnet amphibolites from the upper part of the Careón Sheet (Fig. 8). The mineral lineation in the amphibolites has a consistent E-W orientation, with an associated top-to-the-east sense of shearing (Gómez Barreiro et al., 2010). The imbrication occurred at c. $377 \mathrm{Ma}$, according to the ${ }^{40} \mathrm{Ar} /{ }^{39} \mathrm{Ar}$ dating of hornblendes from the amphibolitic foliation (Dallmeyer et al., 1997).

The Careón Ophiolite was initially interpreted as having been generated in an intra-Rheic Ocean supra-subduction zone (Díaz García et al., 1999; Sánchez Martínez et al., 2007a), beneath which was subducted almost all of the old dense oceanic lithosphere of the Rheic Ocean. Thus, common N-MORB compositional types have not been clearly described so far in the Variscan Belt. The youngest lithosphere generated in this intra-Rheic subduction zone at c. 395 Ma would have been buoyant, and was accreted shortly after its formation at $\mathrm{c}$. $377 \mathrm{Ma}$, below the southern margin of Laurussia. These are now the most common ophiolites in the Variscan suture. This initial interpretation will be discussed in the following sections in the light of new data obtained from the other Upper Ophiolitic Units. isotope geochemistry of the amphibolitic rocks also indicates important isotopic heterogeneity of the mafic material (Murphy and Gutierrez-Alonso, 2008; Sánchez Martínez et al., 2011). The Purrido amphibolites show intense plano-linear foliation development in the amphibolite facies which has been dated at $391.3 \pm 6.6 \mathrm{Ma}$ $\left({ }^{40} \mathrm{Ar} /{ }^{39} \mathrm{Ar}\right.$ in hornblendes; Dallmeyer et al., 1997).

The geochemical and geochronological data provided by the Purrido Ophiolite are interpreted as reflecting interaction between Devonian gabbroic magmas and continental crust. This interpretation calls into question the initially proposed origin for the Upper Ophiolitic Units in an intra-Rheic Ocean subduction zone, seeming to indicate a different tectonic and paleogeographic setting. This new interpretation will be discussed below in the context of a new model for the origin and tectono-thermal evolution of the terranes incorporated in the Variscan suture.

\section{Moeche Ophiolite}

The Moeche Ophiolite crops out widely in the eastern part of Cabo Ortegal Complex (Fig. 2). The Moeche and Purrido ophiolites are in contact in a small coastal section to the West of Cedeira village, where the Moeche Ophiolite occupies the lower structural position. This ophiolitic unit consists of c. $500 \mathrm{~m}$ of greenschists with abundant intercalations of phyllites and mica schist and scarce metagabbros and serpentinites (Fig. 9). Th-Hf-Ta plots for the metabasites (Wood, 1980) indicate chemical compositions transitional between N-MORB and island-arc tholeiites. They show a slight enrichment of trace element abundances relative to N-MORB (Sánchez Martínez et al., 2007b) (Fig. 4f). 


\section{CAREÓN UNIT}

\section{LITHOLOGIES}

Ultramafic rocks

Isotropic metagabbro

[E- Pegmatoid metagabbro

匳 Late pegmatoid metagabbro

$\square$ Wehrlite sills

Felsic rocks

Orosa sheet amphibolites

Diabase

Late diabase

Serpentinite mylonite

\$ Metamorphic sole

- Corundum

Garnet amphibolite

\section{TEXTURES}

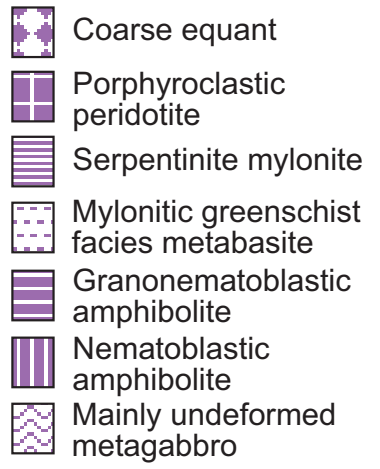

METAMORPHIC FACIES

- Amphibolite

- Epidote amphibolite

- Greenschist

.... High- $T$ foliation

\section{DEFORMATION}

m Detachment fault

$\rightleftharpoons$ Folded and sheared
$\rightleftharpoons$ ultramafic lenses

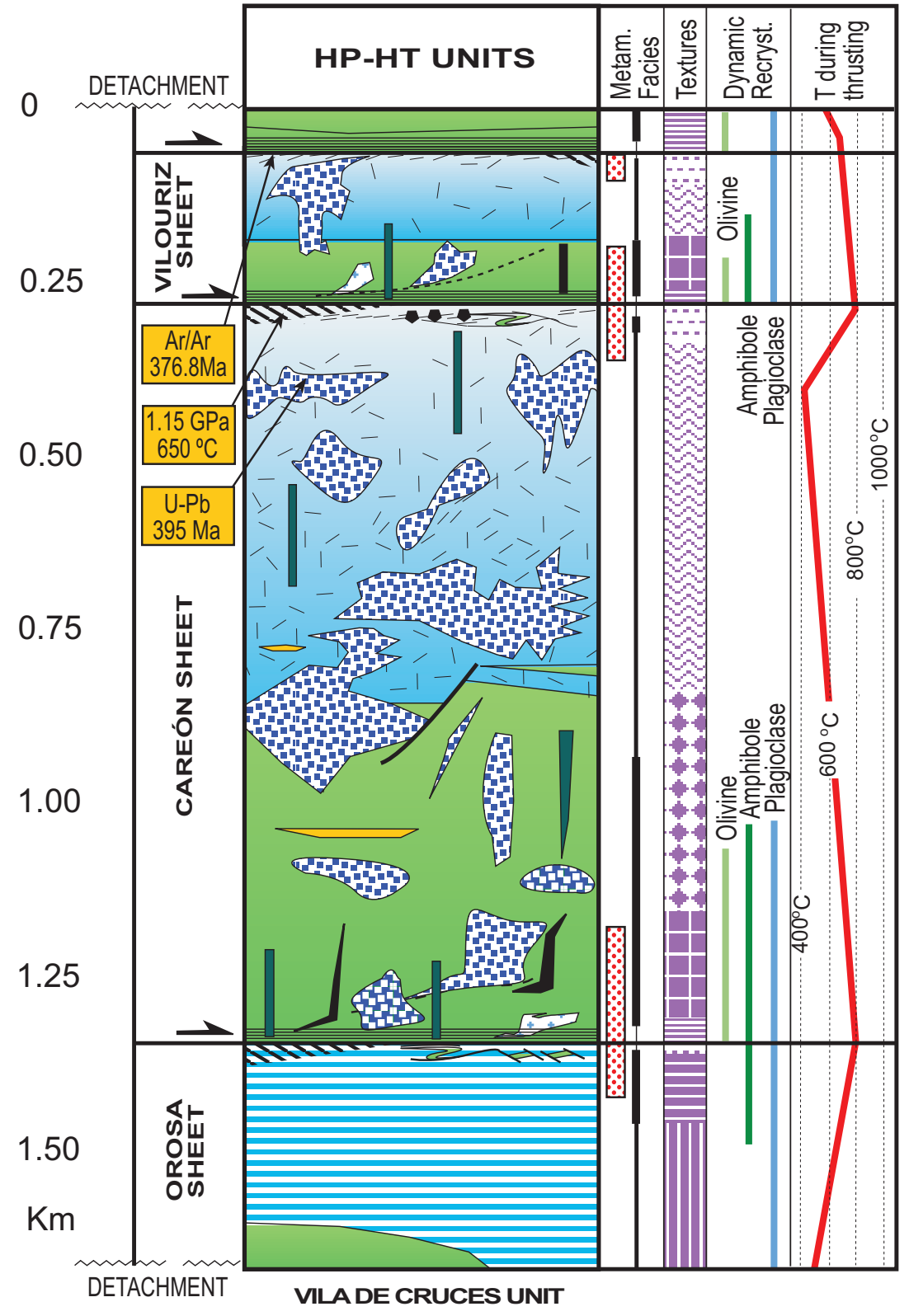

Fig. 8. Synthetic column of the Careón Ophiolite showing the main lithologies and imbricates, distribution of metamorphic facies, textures, levels where dynamic recrystallization of main components occurred, and the saw-tooth thermal gradients developed during the earliest stages of thrusting. The U-Pb age of the gabbroic protoliths, ${ }^{40} \mathrm{Ar}{ }^{39} \mathrm{Ar}$ age of hornblende in metamorphic soles and the peak P-T conditions reached during the accretion are also shown. Modified from Díaz García et al. (1999).

$\mathrm{U}-\mathrm{Pb}$ dating of zircons from a mylonitic greenschist yield an age of $400 \pm 3 \mathrm{Ma}$ (Arenas et al., 2014b) which is comparable to the ages obtained in Careón and Purrido ophiolites. Lu-Hf isotope signatures of the zircons clearly indicate contributions from a continental source. $\varepsilon H f$ values in the analyzed zircons are negative (generally below $\varepsilon \mathrm{Hf}=-5$ ), and hence they are not compatible with crystallization from a juvenile mantle source (Fig. 10). Isotopic Hf data from the zircons of the Moeche Ophiolite are similar to those from the Purrido Ophiolite. These data are again incompatible with formation in an oceanic setting far from continental domains.

The internal structure of the Moeche Ophiolite is poorly known. It displays a regional foliation in greenschist facies conditions which generally has mylonitic-ultramylonitic character. This hinders the recognition of the original nature of the mafic igneous protoliths which have been regarded as both basaltic and gabbroic. The regional foliation is axial planar to tight outcrop-scale recumbent folds. ${ }^{40} \mathrm{Ar} /$ ${ }^{39} \mathrm{Ar}$ dating of the mylonitic foliation in the phyllite intercalations has provided an age of c. $364 \mathrm{Ma}$ (whole rock analysis; Dallmeyer et al., 1997), which is slightly younger than the other regional fabrics dated in the Upper Ophiolitic Units.

\section{Somozas Mélange}

The lowest part of Cabo Ortegal Complex includes a thick tectonic mélange which is only represented in this part of the allochthonous complexes of the NW Iberian Massif (Fig. 2). This tectonic mélange 

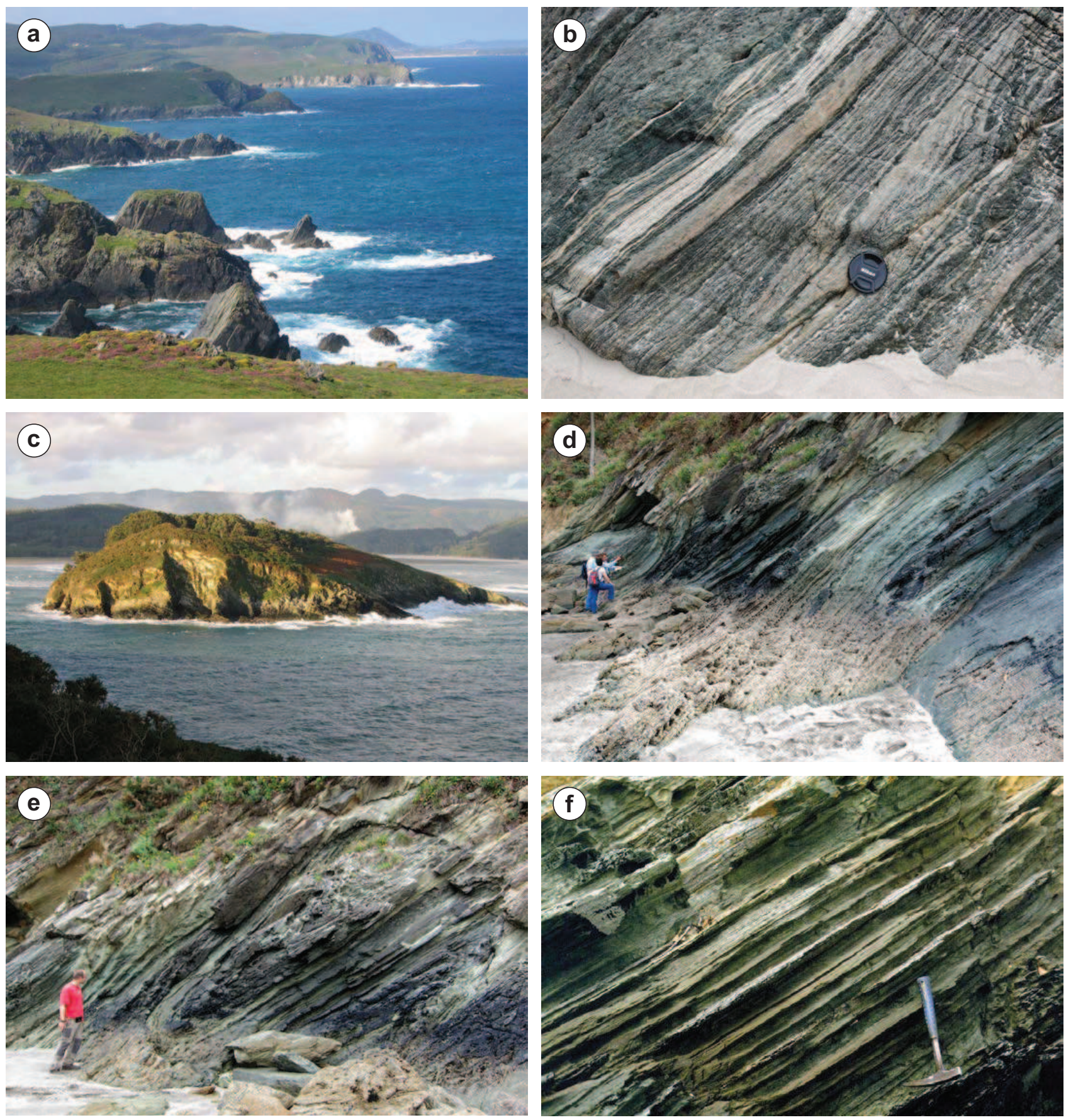

Fig. 9. Field aspects of the Purrido and Moeche ophiolites. (a) Exposures of the Purrido Ophiolite in the western coastal sections of the Cabo Ortegal Complex (foreground). (b) Banded Purrido amphibolites in Baleo beach; these show thick intra-foliation folds. (c) Moeche Ophiolite exposed in San Vicente Island, in the eastern section of the Cabo Ortegal Complex. (d, e, f) Typical mylonitic greenschists of the Moeche Ophiolite in San Vicente island. Observe the large recumbent folding present in this unit, well shown in photograph (e).

is located in the advancing front of the large thrust sheet represented by the allochthonous complexes. The Somozas Mélange was initially described by Arenas et al. (1986), Arenas (1988) and Marcos et al. (2002). More recently, Arenas et al. (2009) presented a detailed map of the mélange in addition to whole-rock geochemical data of the igneous rocks and some $\mathrm{U}-\mathrm{Pb}$ zircon ages.

The Somozas Mélange is better exposed in the southern part of Cabo Ortegal Complex, where it comprises a c. $1800 \mathrm{~m}$ thick unit composed of two contrasting members (Fig. 2). The upper member is c. $800 \mathrm{~m}$ thick and is a mélange with a strongly sheared serpentinite matrix. This matrix surrounds tectonic blocks ranging from metrehectometre to kilometre sizes. The tectonic blocks consist of gabbro, diabase, granitoid, metabasalt, andesitic basalt, pillow breccia, pillow lava, hyaloclastite, marble, phyllite, sandstone and conglomerate, together with HT metamorphic rocks including orthogneisses, common amphibolite and zoisite-rutile rich metabasites (Fig. 11). Many of these tectonic blocks are exotic: their source rocks have not been identified in the allochthonous complexes or the Parautochthon. The lower member is c. $1000 \mathrm{~m}$ thick and it is composed of a mélange with a matrix of ochre colored phyllites or 


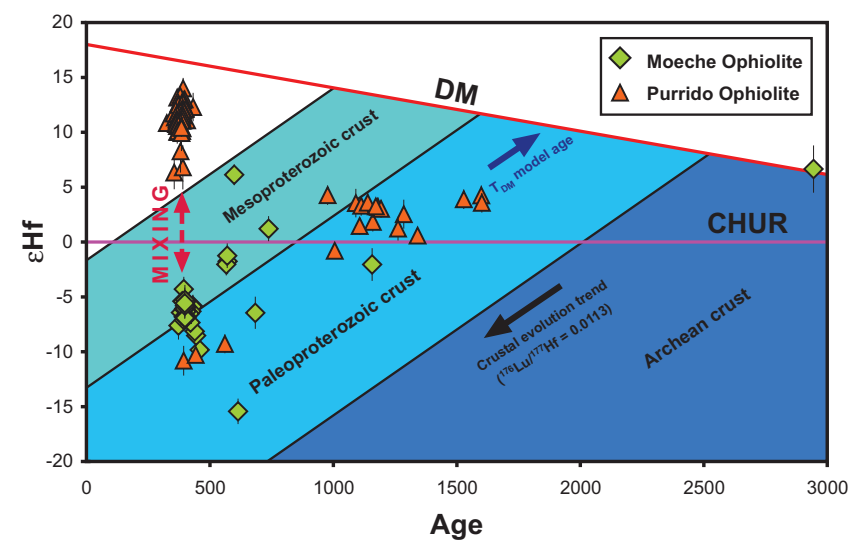

Fig. 10. $\varepsilon H f$ versus age diagram combining the $\mathrm{U}-\mathrm{Pb}$ and $\mathrm{Lu}-\mathrm{H} f$ isotope data of zircons from the Purrido and Moeche ophiolites. Crustal evolution trends $\left({ }^{176} \mathrm{Lu} /{ }^{177} \mathrm{Hf}=0.0113\right)$ for the Archean, Paleoproterozoic and Mesoproterozoic crusts are also shown. Based in Sánchez Martínez et al. (2011) and Arenas et al. (2014b).

blue colored phyllonites surrounding tectonic blocks of the lithologies incorporated into the serpentinite mélange. No HP rocks have been described so far in the Somozas Mélange, although some of the high$\mathrm{T}$ tectonic blocks reached at least the highest pressure conditions of
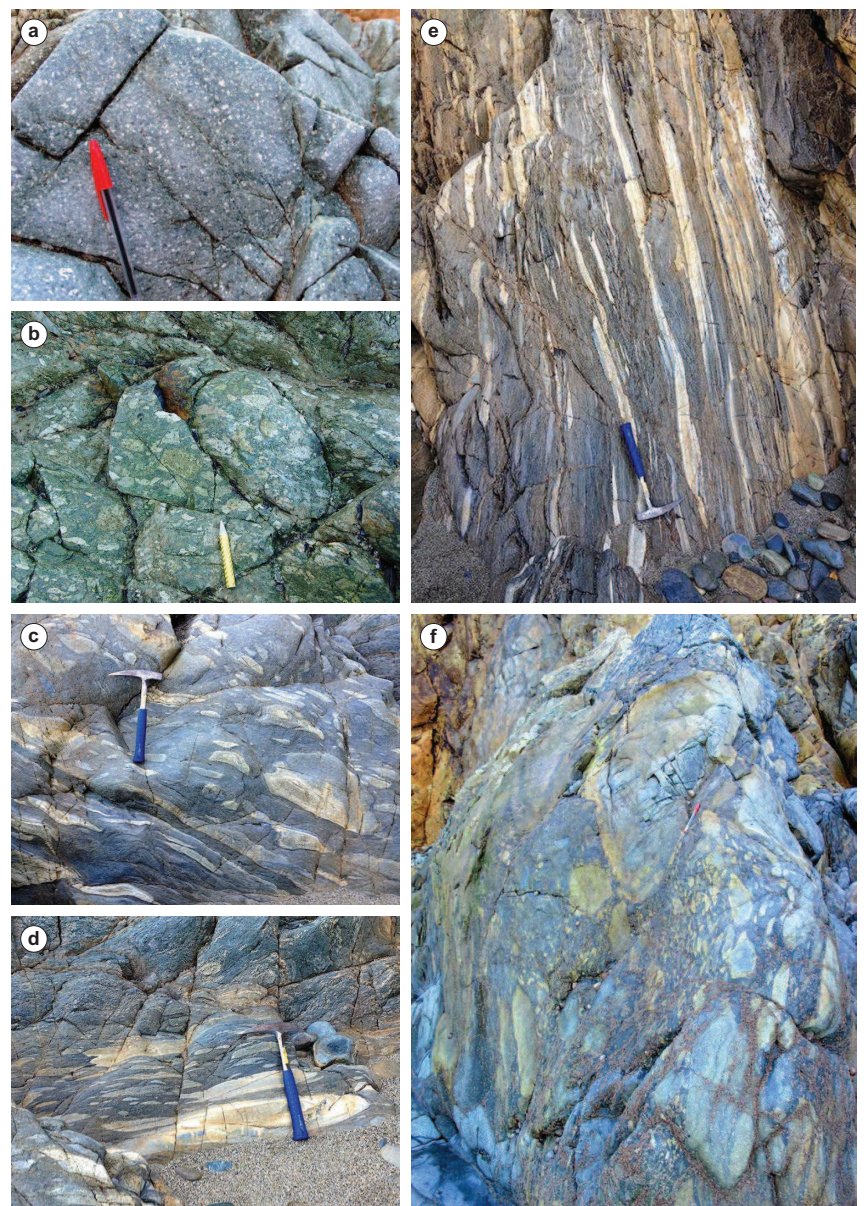

Fig. 11. Field aspects of tectonic blocks in the Somozas Mélange. (a) Massive basaltic andesites. (b) Broken pillow-breccia. (c, d) Sheared pillow breccias with local presence of intrusive diabase dykes. (e) Strongly sheared pillow breccias. $(f)$ Undeformed pillow breccia with preserved large whole pillows. the amphibolite facies. However, a detailed study of all mineral assemblages has not yet been made.

$\mathrm{U}-\mathrm{Pb}$ zircon dating was undertaken on a tonalitic orthogneiss from a large high-T tectonic block and on two few deformed granitoids affected by low-grade recrystallization (Arenas et al., 2009). The HT orthogneiss yields an age of c. 485 Ma (SHRIMP), and the two granitoids yield ages of c. $499 \mathrm{Ma}$ (SHRIMP) and c. $527 \mathrm{Ma}$ (LAICP-MS). Whole rock geochemistry of all the igneous rocks in the mélange, whether volcanic, plutonic or dykes, points to a volcanic arc setting (Fig. 4c). A negative $\mathrm{Nb}$ anomaly is exhibited by all lithologies, a feature considered an indication of a supra-subduction zone setting (Fig. 4c). Furthermore, the U-Pb ages of detrital zircon populations present in a block of conglomerate indicate a maximum age of sedimentation at about the Early-Middle Ordovician boundary and deposition at the paleo-margin of Gondwana with a typical WestAfrican provenance (Arenas et al., 2009).

$\mathrm{U}-\mathrm{Pb}$ geochronology and whole rock geochemistry data indicate that the Somozas Mélange contains abundant materials derived from a peri-Gondwanan magmatic arc. This observation suggests that the margin of Gondwana itself might have participated in the formation of the mélange, although the exact time of mélange formation is unknown. However, the position of the mélange also suggests a relationship with the subduction and accretion that affected the Basal Units. The upper section of the Somozas Mélange is a typical serpentinite mélange. Its formation implies the existence of active subduction for a protracted period, with generation of a low viscosity channel in the overlying mantle (Gerya et al., 2002; Hebert et al., 2009). The lower section of the mélange was developed later and represents an imbrication zone of the upper serpentinite melange with the higher levels of the Parautochthon. Thus the time of formation of the Somozas Mélange can be roughly constrained between the age of the subduction, which affected the Basal Units (c. $370 \mathrm{Ma}$; Abati et al., 2010), and the age of the imbrication with the Parautochthon. That date is, at present, unknown, but logically should be similar to or slightly earlier than the age estimated for the basal thrust of the Parautochthon above the Central Iberian Zone (c. 343 Ma; Dallmeyer et al., 1997).

\section{Paleozoic oceans and the assembly of Pangea}

Based on the U-Pb chronology obtained for their most representative lithologies, the ophiolites of NW Iberian Massif are of two main age groups: Cambrian (Lower Ophiolitic Units) and Devonian (Upper Ophiolitic Units). The Somozas Mélange is a separate unit, the age of which is not known precisely. The main Ophiolitic Units (excepting the Bazar Ophiolite) show chemical compositions related to supra-subduction zones or pull-apart basins. This interpretation is also compatible with the lithological features of the best preserved ophiolitic sections, such as the Careón Ophiolite. Thus, the age of the ophiolites involved in the Variscan suture spans much of the Paleozoic; significantly, the time range between the opening and closure of the main Paleozoic ocean generated in the peri-Gondwana context (the Rheic Ocean). Moreover, the youngest ophiolites are approximately coeval with the first tectono-thermal events related to the assembly of Pangea. The Variscan suture therefore has specific features that throw light on the relationship between the opening and closure of a large oceanic domain, and complex tectono- 
thermal episodes culminating in the final assembly of a supercontinent.

The Upper Units of the allochthonous complexes have been interpreted as a section of a peri-Gondwanan arc, rifted from the mainland in Cambrian-Early Ordovician times during the opening of the Rheic Ocean (Fig. 12). That rifting should be contemporary with that of the Avalonia microcontinent (Murphy et al., 2006), although the terrane represented by the Upper Units had a distinct identity and provenance from further east along the paleomargin of Gondwana (Abati et al., 2007; Gómez Barreiro et al., 2007) (Fig. 12). The HP-UHP metamorphism affecting the lower part of the Upper Units at c. 400-390 Ma would have developed during the accretion of this terrane to the southern margin of Laurussia and would have defined the change to a convergent regime in the Rheic Ocean domain (Gómez Barreiro et al., 2007; Sánchez Martínez et al., 2007a). The evolution proposed for the Upper Units implies that the Variscan suture ophiolites were generated within the Rheic Ocean realm. The Cambrian ophiolites, excepting the Bazar Ophiolite, would be linked to the initial stages of the opening of this ocean reminiscent of the Western Alps Tethys (Dilek and Furnes, 2014; Balestro et al. 2015; Saccani et al. 2015), whereas the Devonian ophiolites would have originated during the final stages of its closure (Arenas et al., 2007a) analogous to many supra-subduction zone ophiolites (Dilek, 2003; Dilek and Furnes, 2011; Yang et al. 2015). The Devonian ophiolites, the commonest in the Variscan suture, have been interpreted as suprasubduction zone ophiolites generated at the intraRheic subduction zone located near the Southern margin of Laurussia (Díaz García et al., 1999; Sánchez Martínez et al., 2007a). This subduction zone would have generated buoyant oceanic lithosphere that would have accreted soon after, below the Upper Units then constituting the Southern margin of Laurussia, and later thrust above the most external margin of Gondwana (Basal Units), at the onset of the Variscan deformation (c. $370 \mathrm{Ma}$ ). The activity of the intra-Rheic Ocean subduction zone also would explain the widespread absence in the Variscan Belt of N-MORBtype oceanic lithosphere typical of the Rheic Ocean, which would have been completely eliminated by subduction.

It is implausivle, however, to interpret in this model the Devonian ophiolites as remnants of oceanic lithosphere formed in open oceanic domains. The new isotope geochemistry data indicate that the gabbroic protolith interacted with ancient continental crust. Many existing zircons in mafic rocks of the Purrido and Moeche ophiolites show a $\mathrm{Lu}-\mathrm{Hf}$ isotope composition that is only compatible with a continental origin. Therefore, they must be interpreted as inherited zircons in the mafic magma (Sánchez Martínez et al., 2011; Arenas et al., 2014b). However, there is no conclusive data to connect the generation of the Devonian ophiolites with the evolution of the Rheic Ocean, therefore it is not possible to assert that the suture zone they define was a consequence of its closure. If the suture zone of NW Iberia is not linked to the evolution of the Rheic Ocean, the main argument for considering the Upper Units as a terrane drifted to the North from Gondwana during the opening of this oceanic domain is not supported. However, there are also problems for the possible development of an episode of HP-UHP metamorphism in a small peri-Gondwana terrane colliding with Laurussia. That type of tectono-thermal evolution is generally associated with deep subduction of the thinned margin of a large continental landmass (Warren et al., 2008; Beaumont et al., 2009).

Regarding the HP-UHP event of the Upper Units, the existing U$\mathrm{Pb}$ geochronological data indicate that it took place at c. 400-390 Ma (Ordóñez Casado et al. 2001; Fernández Suárez et al. 2007) approximately coincident with the age of the mafic rocks of the 
Upper Ophiolitic Units, which has been repeatedly dated by U-Pb geochronology at c. 400-395 (Díaz García et al., 1999; Pin et al., 2002, 2006; Sánchez Martínez et al., 2011; Arenas et al., 2014b). For the HP metamorphic event, the U-Pb geochronology may reflect the age of zircon growth that took place at high temperatures and therefore would have occurred later than the onset of deformation and the metamorphism itself. The subduction affecting this section of the volcanic arc would logically have started before 400-390 Ma, although it is not possible to know the precise age and, therefore, must have occurred prior to the generation of the Devonian ophiolites.

The recently obtained data, especially the Lu-Hf isotope data from the zircons of the Devonian ophiolites and detailed U-Pb geochronology of the HP metamorphic events, favor an alternative interpretation to that initially proposed for the allochthonous terranes of the Variscan suture of the NW Iberian Massif. These data suggest two successive stages of collision between Gondwana and Laurussia, which took place in a context of dextral convergence, separated in time by the opening of a relatively wide, probably a pull-apart, oceanic basin (Arenas et al., 2014a).

The Upper Units are considered the most external part of the continental platform of Gondwana. That platform was probably very wide and composed of a thick turbidite series intruded by large bodies of gabbros and granitoids. Its origin was related to the activity of a volcanic arc during Cambrian-Early Ordovician times that later

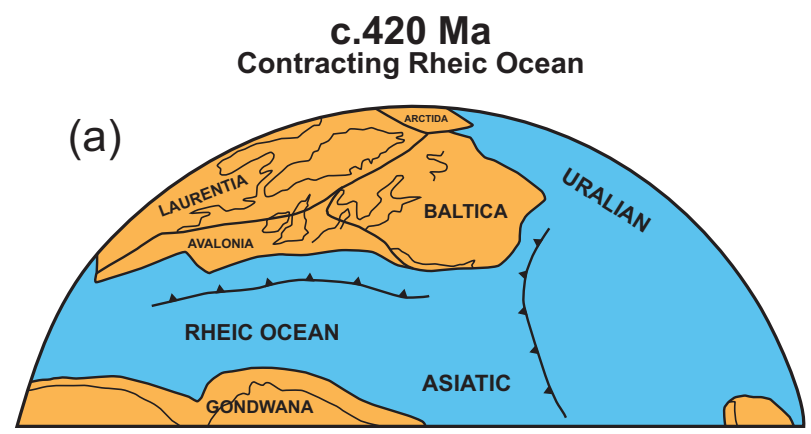

c. $395 \mathrm{Ma}$

Generation of an oceanic microplate

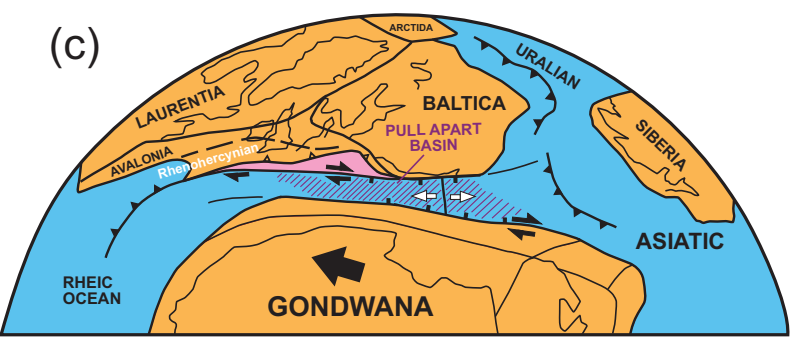

UPPER UNITS underwent strong extension and subsequent thinning. As evidence of renewed igneous or deformational activity was not preserved in the platform until the beginning of the Devonian HP-UHP metamorphic event, this must have been a typical passive margin during much of Ordovician and Silurian times, with no evidence for its separation from the mainland. Convergence between Gondwana and Laurussia favored the development of a first collision and subduction to the north of the most external section of the platform which underwent the HP-UHP event prior to c. 400-390 Ma. The interaction between the two large continents allowed the deep subduction of the thinned prograde margin of Gondwana. The southern margin of Laurussia acted as a retro-continent and the most important collision probably took place along the eastern part of Avalonia and, perhaps, along the margin of Baltica (Fig. 13).

Continued dextral convergence favored the fast development of a wide pull-apart basin during the Lower Devonian, in which mafic rocks would have been generated at c. 395 Ma constituting, later, the typical ophiolites of the Variscan suture (Fig. 13). A modern equivalent for this setting can be found in the pull-apart basin generated between the North American Plate and the Caribbean Plate, although in that case the continental convergence shows sinistral motion. There, the Gonâve microplate, occupying the pull-apart basin, is comprised of oceanic-type lithosphere, generated by the activity of the Mid-Caiman Spreading Centre, and scarce or nonexistent

\section{c. 410-400 $\mathrm{Ma}$} First collision: HP-UHP - event

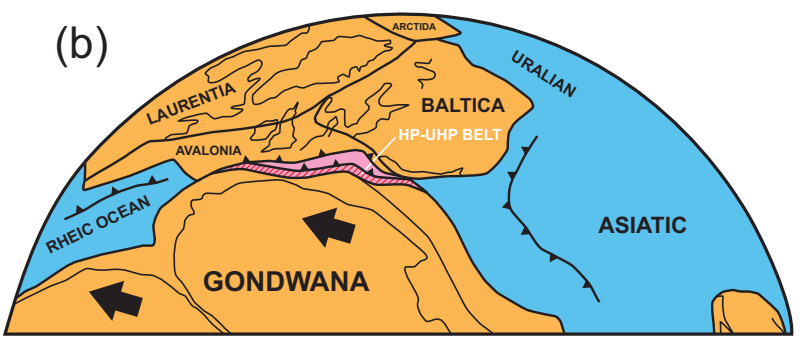

c. $380-370 \mathrm{Ma}$

Second collision: Ophiolite obduction and second HP - event

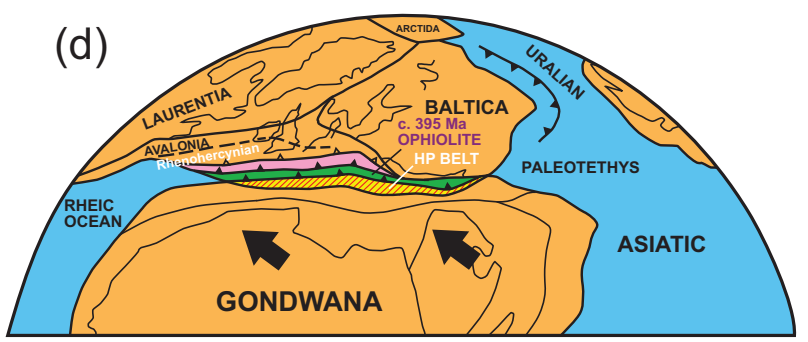

OPHIOLITIC UNITS

BASAL UNITS

Fig. 13. Reconstruction of the Rheic Ocean realm at the Silurian-Devonian boundary (a), and the initial collision between Gondwana and Laurussia at c. 410-400 Ma following the complete closure of the Rheic Ocean (b). This collision caused subduction of a section of the margin of Gondwana and generated the HP-UHP metamorphic belt preserved in the allochthonous Upper Units exposed in the Variscan suture. The true Rheic Ocean suture is not represented in NW Iberia. Dextral motion between Gondwana and Laurussia favored the opening of a rather ephemeral pull-apart basin at c. 395 Ma with generation of new oceanic lithosphere (c). The second and final collision at c. 380-370 Ma caused the accretion of buoyant oceanic lithosphere followed by new subduction affecting the margin of Gondwana, thereby developing a second HP-LIT metamorphic belt (d). The two different HP belts and the ophiolitic units dated at c. 395 Ma can be identified in the allochthonous terranes which outline the Variscan suture from Iberia to the Bohemian Massif. Modified after Arenas et al. (2014a). 
sedimentary cover (Brink et al., 2002). In this modern example, as apparently occurred in the inception of Pangea, the pull-apart basin was generated after an initial collision event between the two plates that currently limit the basin (García Casco et al., 2008; Sommer et al., 2011).

The dextral convergence of Gondwana finally facilitated the closure of the basin and the initial accretion of buoyant oceanic lithosphere below the northern continent after c. $380 \mathrm{Ma}$; the age of the prograde foliation in the Careón and Purrido ophiolites (Dallmeyer et al., 1997). This lithosphere escaped the renewed subduction while undergoing amphibolite facies regional metamorphism, although some metamorphic soles with local growth of corundum indicate the local occurrence of high thermal gradients (Díaz García et al., 1999). The imbrication of new mafic sheets took place under a lower greenschist facies thermal regime, favoring the accretion of the other sheets of Devonian ophiolites (Moeche Ophiolite) and other older mafic sequences generated by the activity of the peri-Gondwanan magmatic arc (Vila de Cruces Ophiolite). The result was a complex suture zone developed during protracted dextral convergence and containing two ophiolitic belts of different ages, the Cambrian Lower Ophiolitic Units and Devonian Upper Ophiolitic Units. The existence of a thick serpentinitic mélange at the base of the allochthonous pile, the Somozas Mélange, has also been interpreted in the context of dextral convergence (Arenas et al., 2009).

The final collision between Laurussia and Gondwana, as a consequence of oblique convergence, took place at c. 370Myr (Díez Fernández et al., 2012c). It initiated a renewed north-directed subduction of the outer section of the most external thinned margin of Gondwana, this time with easternmost provenance (Basal Units; Díez Fernández et al., 2010; Fuenlabrada et al., 2012). Thus a second HP metamorphic event was generated, in this instance of LIT, originating C-Type eclogites, blueschists and HP metapelites (Fig. 13). The convergence went on during a long period of progressive intra-continental deformation, which propagated to the south, thereby affecting the margin of Gondwana and reaching the external Variscan areas about 40-50 Ma later (Dallmeyer et al., 1997).

\section{Classification of the NW Iberia ophiolites}

Dilek and Furnes $(2011,2014)$ presented a new classification of ophiolites according to their geochemical signature and internal structure. They distinguished two first order groups: subductionunrelated and subduction-related ophiolites. The first type includes continental margin $(\mathrm{CM})$, mid-ocean ridge (MOR) and plume-type (P) ophiolites. CM ophiolites are formed during continental rifting and generation of an incipient ocean. In subsequent stages of lithospheric extension and seafloor spreading the resulting ophiolite type is MOR, whose features may vary depending on the spreading rate at the ridge (fast, intermediate or slow spreading ridges). $\mathrm{P}$ type ophiolites form at plume-proximal oceanic ridges or as part of oceanic plateaus. Subduction related ophiolites include supra-subduction zone (SSZ) and volcanic arc (VA) ophiolites. SSZ ophiolites represent oceanic lithosphere formed in the extended upper plates of subduction zones (Dilek and Furnes, 2011). The tectonic setting for the oceanic crust forming these ophiolites includes the fore-arc, the back arc and the incipient arc. Within back-arc tectonic environments it is possible to distinguish trench-proximal or trench-distal spreading centers depending on the extent of subduction influence. Furthermore, it would be possible to differentiate SSZ oceanic or continental back- arc basin ophiolites whether they resulted from seafloor spreading in "ensimatic" or "ensialic" settings. VA ophiolites differ from SSZ in a thicker and more fully developed arc crust with calc-alkaline geochemical signatures and the presence of more varied igneous lithologies.

In the case of the NW Iberia ophiolites, the Bazar ophiolite is the only one which does not record a clear influence of a subduction zone in the generation of its igneous protoliths (Fig. 4). Consequently it can be classified as an ophiolite unrelated to subduction, most probably of the MOR type (Fig. 6). As discussed before, it probably represents Cambrian (c. $495 \mathrm{Ma}$ ) peri-Gondwanan oceanic lithosphere, accreted during Early Ordovician times (c. 475 Ma), shortly after its generation at the ridge. Given this particular evolution mode and the geochemical features of its lithologies as transitional between N-MORB and E-MORB similar to the trench-proximal Taitao ophiolite in Southern Chile (Le Moigne et al., 1996), it is not possible to discard the possibility that part of the oceanic lithosphere was generated while the ridge was subducted (ridge-subduction ophiolite, according to the classification of Pearce, 2014) (Fig. 6).

The igneous lithologies of the Vila de Cruces ophiolite (c. 500 Ma) show geochemical features clearly indicative of an origin related with the activity of a subduction zone (Fig. 4). It can be classified as a subduction-related SSZ type of ophiolite generated in a back-arc basin (Fig. 6). The significant negative $\mathrm{Nb}$ anomalies suggest a trench proximal position of the basin, and, given the important amount of sediment contained in the ophiolite (Fig. 2), as well as the evidence of interaction between the igneous protoliths and the continental crust, it would probably represent a continental backarc basin (Dilek and Robinson, 2003, and references therein).

The classification of the Devonian (c. 395 Ma) ophiolites (Careón, Purrido and Moeche) following the guidelines of Dilek and Furnes $(2011,2014)$ is more complicated. We have interpreted the tectonic setting where the oceanic lithosphere formed as a pull-apart basin formed after a first collision between Gondwana and Laurussia (Fig. 13). Nevertheless, it is clear that subduction zone influence does exist as it is recorded by the geochemistry of the associated mafic rocks (Fig. 4). It is noticeable that such subduction components vary from one ophiolite to another, being more significant in Careón and progressively attenuating in Purrido and even more in Moeche. The most plausible interpretation of this observation is that this pull-apart basin opened within a back-arc basin, which persisted after the initial collision. In this context, variation of the influence of the subduction zone depended on the proximity of the spreading ridge of the pullapart basin to the original trench. Thus, applying the new ophiolite classification, it is clear that the Devonian ophiolites are in general terms of subduction-related SSZ type.

Finally, to apply the new ophiolite classification to the Somozas Mélange, we should first address the problem of the origin of that unit. The development of the mélange itself was distinct from the origin of the igneous lithologies forming part of the tectonic blocks. They should represent at least in part sections of an oceanic sequence, as the development of a low viscosity channel in the lithospheric mantle implies dehydration of its mafic components during subduction. The compositions of the mafic lithologies (c. 527-485 $\mathrm{Ma}$ ) present in the mélange show a clear participation of a subduction component (Fig. 4). Therefore, the ophiolitic components included in this serpentinite mélange are of SSZ type, and were developed in relation to a Cambrian subduction zone active in the peri-Gondwanan realm. 


\section{Conclusions}

In the NW Iberian Massif, two main groups of ophiolites are preserved in the Variscan suture: Cambrian (c. $500 \mathrm{Ma}$; Lower Ophiolitic Units) and Devonian (c. 395 Ma; Upper Ophiolitic Units). A thick serpentinitic mélange of uncertain age and origin is also present. These ophiolites are composed of mafic sequences with minor strongly deformed ultramafic rocks metamorphosed from greenschist to low-P granulites facies. Although the primary mineralogy is not preserved, the plutonic, intrusive and volcanic textures and structures are frequently observed. Sedimentary rocks are rather scarce and it is unclear whether their presence in the ophiolite has tectonic significance.

The lithological and geochemical features of most of these ophiolites show that they are not of common MOR types. They instead formed in a supra-subduction zone setting (SSZ) or during the opening of pull-apart type ephemeral basins. Perhaps, the only exception is the Bazar Ophiolite, which has a more representative oceanic composition that seems to reflect a Cambrian accretion zone of peri-Gondwanan oceanic material below a magmatic arc system. This, together with the Vila de Cruces Ophiolite, also generated during Cambrian times in relation to the opening of a back-arc basin, reflects, to some extent, the earliest stages of the opening of the Rheic Ocean, the largest Paleozoic ocean generated in the peri-Gondwanan setting.

The Devonian ophiolites (Careón, Purrido and Moeche ophiolites) were previously interpreted to have been generated at an intra-Rheic Ocean supra-subduction zone. This subduction zone would have been responsible for the removal of almost all the lithosphere of the Rheic Ocean. However, recent isotopic data (Lu-Hf in zircon) clearly indicates that the source of the mafic rocks of these ophiolites interacted with continental crust. Therefore they are better interpreted as remnants of an oceanic lithosphere generated in an ephemeral basin, probably of a pull-apart type, developed during dextral convergence. That basin probably opened at c. 400-390 Ma, apparently after a first interaction between the continental margins, which triggered the HPUHP metamorphism in the subducted margin of Gondwana. Its total closure occurred at c. $370 \mathrm{Ma}$, when the Gondwana margin underwent a second event of subduction and HP metamorphism. The buoyant oceanic crust of this ephemeral basin was accreted at high-T, below the terrane which currently constitutes the Upper Units of NW Iberian Massif.

The two ophiolitic belts in Galicia preserve evidence for the complex tectono-thermal events that occurred during the assembly of Pangea. This collision was not simple, but occurred in at least two distinct events separated by the opening of pull-apart basins. In addition, the tectono-thermal events related to the assembly of Pangea seem to start by c. $390 \mathrm{Ma}$, considerably earlier than previously considered, and thus they lasted longer. Therefore, the conclusions presented in this paper indicate that the early events in the assembly of Pangea are more complex than previously described. Nevertheless, these findings are not surprising since the history of convergence and collision between two large continental masses is commonly not simple, and complexity is the norm rather than the exception, as can be observed in some modern examples of continental convergence.

\section{Acknowledgements}

Financial support has been provided by the Spanish project
CGL2012-34618 (Ministerio de Economía y Competitividad). Insightful reviews by Brendan Murphy and J.A. Winchester are kindly acknowledged.

\section{References}

Abati, J., Dunning, G.R., Arenas, R., Díaz García, F., González Cuadra, P., Martínez Catalán, J.R. and Andonaegui, P, 1999, Early Ordovician orogenic event in Galicia (NW Spain): evidence from U-Pb ages in the uppermost unit of the Ordenes Complex: Earth and Planetary Science Letters, v. 165, pp. 213-228.

Abati, J., Castiñeiras, P., Arenas, R., Fernández-Suárez, J., Gómez-Barreiro, J. and Wooden, J., 2007, Using SHRIMP zircon dating to unravel tectonothermal events in arc environments. The early Palaeozoic arc of NW Iberia revisited: Terra Nova, v. 19, pp. 432-439.

Abati, J., Gerdes, A., Fernández-Suárez, J., Arenas, R., Whitehouse, M.J. and Díez Fernández, R., 2010, Magmatism and early-Variscan continental subduction in the northern Gondwana margin recorded in zircons from the basal units of Galicia, NW Spain: Geological Society of America Bulletin, v. 122, pp. 219-235.

Albert, R., Arenas, R., Gerdes, A., Sánchez Martínez, S., Fernández-Suárez, J. and Fuenlabrada, J.M., 2015, Provenance of the Variscan Upper Allochthon (Cabo Ortegal Complex, NW Iberian Massif): Gondwana Research. Gondwana Research, v. 28, pp. 1434-1448. DOI.org/10.1016/ j.gr.2014.10.016

Andonaegui, P., Castiñeiras, P., González Cuadra, P., Arenas, R., Sánchez Martínez, S., Abati, J., Díaz García, F. and Martínez Catalán, J.R., 2012, The Corredoiras orthogneiss (NW Iberian Massif): Geochemistry and geochronology of the Paleozoic magmatic suite developed in a periGondwanan arc: Lithos, v. 128-131, pp. 84-99.

Arenas, R., 1988, Evolución petrológica y geoquímica de la unidad alóctona inferior del Complejo Metamórfico Básico - Ultrabásico de Cabo Ortegal (Unidad de Moeche) y del Silúrico Parautóctono (NW de España): Corpus Geologicum Gallaeciae, v. 4, 543 p.

Arenas, R., Gil Ibarguchi, J.I., González Lodeiro, F., Klein, E., Martínez Catalán, J.R., Ortega Gironés, E., Pablo Maciá, J.G. de and Peinado, M., 1986, Tectonostratigraphic units in the complexes with mafic and related rocks of the NW of the Iberian Massif: Hercynica, v. 2, pp. 87-110.

Arenas, R., Rubio Pascual, F.J., Díaz García, F. and Martínez Catalán, J.R., 1995, High-pressure microinclusions and development of an inverted metamorphic gradient in the Santiago Schists (Órdenes Complex, NW Iberian Massif, Spain): evidence of subduction and syn-collisional decompression: Journal of Metamorphic Geology, v. 13, pp. 141-164.

Arenas, R., Abati, J., Martínez Catalán, J.R., Díaz García, F. and Rubio Pascual, F.J., 1997, P-T evolution of eclogites from the Agualada Unit (Órdenes Complex, NW Iberian Massif, Spain): Implications for crustal subduction: Lithos, v. 40, pp. 221-242.

Arenas, R., Martínez Catalán, J.R., Sánchez Martínez, S., Díaz García, F., Abati, J., Fernández-Suárez, J., Andonaegui, P. and Gómez-Barreiro, J., 2007a, Paleozoic ophiolites in the Variscan suture of Galicia (northwest Spain): distribution, characteristics and meaning, in Hatcher, R.D. Jr., Carlson, M.P., McBride, J.H. and Martínez Catalán, J.R., eds, 4-D Framework of Continental Crust: Geological Society of America Memoir, v. 200, pp. 425-444.

Arenas, R., Martínez Catalán, J.R., Sánchez Martínez, S., Fernández-Suárez, J., Andonaegui, P., Pearce, J.A. and Corfu, F., 2007b, The Vila de Cruces Ophiolite: A remnant of the early Rheic Ocean in the Variscan suture of Galicia (NW Iberian Massif): Journal of Geology, v.115, pp.129-148.

Arenas, R., Sánchez Martínez, S., Castiñeiras, P., Jeffries, T.E., Díez Fernández, R. and Andonaegui, P., 2009, The basal tectonic mélange of the Cabo Ortegal Complex (NW Iberian Massif): a key unit in the suture of Pangea: Journal of Iberian Geology, v. 35, pp. 85-125.

Arenas, R., Díez Fernández, R., Sánchez Martínez, S., Gerdes, A., FernándezSuárez, J. and Albert, R., 2014a, Two-stage collision: Exploring the birth of Pangea in the Variscan terranes: Gondwana Research, v. 25, pp. 756763. 
Arenas, R., Sánchez Martínez, S., Gerdes, A., Albert, R., Díez Fernández, R. and Andonaegui, P., 2014b, Re-interpreting the Devonian ophiolites involved in the Variscan suture: U-Pb and Lu-Hf zircon data of the Moeche Ophiolite (Cabo Ortegal Complex, NW Iberia): International Journal of Earth Sciences, v. 103, pp. 1385-1402.

Balestro, G., Festa, A., Dilek, Y. and Tartarotti, P., 2015, Pre-Alpine Extensional tectonics of a peridotite-localized oceanic core complex in the late Jurassic, high-pressure Monviso ophiolite (Western Alps). Episodes, v. 38, no.4, pp. 266-282, doi:10.18814/epiiugs/2015/v38i4/82421.

Ballèvre, M., Bosse, V., Ducassou, C. and Pitra, P., 2009, Palaeozoic history of the Armorican Massif: Models for the tectonic evolution of the suture zones: Comptes Rendus Geoscience, v. 341, pp. 174-201.

Ballèvre, M., Martínez Catalán, J.R., López Carmona, A., Abati, J., Díez Fernández, R., Ducassou, C., Pitra, P., Arenas, R., Bosse, V., Castiñeiras, P., Fernández-Suárez, P., Gómez Barreiro, J., Paquette, J.L., Peucat, J.J., Poujol, M., Ruffet, G. and Sánchez Martínez, S., 2014, Correlation of the nappe stack in the Ibero-Armorican arc across the Bay of Biscay: a joint French-Spanish project, in Schulmann, K., Martínez Catalán, J.R., Lardeaux, J. M., Janousì, V. and Oggiano, G., eds, The Variscan Orogeny: Extent, Timescale and the Formation of the European Crust: Geological Society of London, Special Publication, v. 405, pp. 77-113.

Beaumont, C., Jamieson, R.A., Butler, J.P and Warren, C.J., 2009, Crustal structure: A key constraint on the mechanism of ultra-high-pressure rock exhumation: Earth and Planetary Science Letters, v. 287, pp. 116-129.

Brink, U.S. ten, Coleman, D.F. and Dillon, W.P., 2002, The nature of the crust under Cayman Trough from gravity: Marine and Petroleum Geology, v. 19 , pp. $971-987$.

Chauvel, C. and Blichert-Toft, J., 2001, A hafnium isotope and trace element perspective on melting of the depleted mantle: Earth and Planetary Science Letters, v. 190, pp. 137-151.

Clark, A.H., Scott, D.J., Sandeman, H.A., Bromley, A.V. and Farrar, E., 1998, Siegenian generation of the Lizard ophiolite: $\mathrm{U}-\mathrm{Pb}$ zircon age data for plagiogranite, Porthkerries, Cornwall: Journal of de Geological Society, London, v. 155, pp. 595-598.

Coleman, R.G., Lee, D.E., Beatty, L.B. and Brannock, W.W., 1965, Eclogites and eclogites - their differences and similarities: Geological Society of America Bulletin, v. 76, pp. 483-508.

Dallmeyer, R.D., Martínez Catalán, J.R., Arenas, R., Gil Ibarguchi, J.I., Gutiérrez Alonso, G., Farias, P., Aller and J., Bastida, F., 1997, Diachronous Variscan tectonothermal activity in the NW Iberian Massif: evidence from ${ }^{40} \mathrm{Ar} /{ }^{39} \mathrm{Ar}$ dating of regional fabrics: Tectonophysics, v. 277, pp. 307-337.

Díaz García, F., 1990, La geología del sector occidental del Complejo de Órdenes (Cordillera Hercínica, NW de España): Nova Terra, v. 3, 230 p.

Díaz García, F., Arenas, R., Martínez Catalán, J.R., González del Tánago, J. and Dunning, G.R., 1999, Tectonic evolution of the Careón Ophiolite (northwest Spain): a remnant of oceanic lithosphere in the Variscan Belt: Journal of Geology, v. 107, pp. 587-605.

Díaz García, F., Sánchez Martínez, S., Castiñeiras, P., Fuenlabrada, J.M. and Arenas, R., 2010, A peri-Gondwanan arc in NW Iberia. II: Assessment of the intra-arc tectonothermal evolution through U-Pb SHRIMP dating of mafic dykes: Gondwana Research, v. 17, pp. 352-362.

Díez Fernández, R., Martínez Catalán, J.R., Gerdes, A., Abati, J., Arenas, R. and Fernández-Suárez, J., 2010, U-Pb ages of detrital zircons from the basal allochthonous units of NW Iberia: Provenance and paleoposition on the northern margin of Gondwana during the Neoproterozoic and Paleozoic: Gondwana Research, v. 18, pp. 385-399.

Díez Fernández, R., Martínez Catalán, J.R., Arenas, R., Abati, J., Gerdes, A. and Fernández-Suárez, J., 2012a, U-Pb detrital zircon analysis of the lower allochthon of NW Iberia: age constraints, provenance and links with the Variscan mobile belt and Gondwana cratons: Journal of the Geological Society, London, v. 169, pp. 655-665.

Díez Fernández, R., Castiñeiras, P. and Gómez Barreiro, J., 2012b, Age constraints on Lower Paleozoic convection system: magmatic events in the NW Iberian Gondwana margin: Gondwana Research, v. 21, pp. 10661079 .
Díez Fernández, R., Martínez Catalán, J.R., Arenas, R. and Abati, J., 2012c, The onset of the assembly of Pangaea in NW Iberia: Constraints on the kinematics of continental subduction: Gondwana Research, v. 22, pp. 20-25.

Dilek, Y., 2003, Ophiolite pulses, mantle plumes and orogeny. Geological Society of London, Sepcial Publications, v. 218, pp. 9-19.

Diley, Y. and Robinson, P.T., 2003, Ophiolites in Earth history. Geological Society, London, Special Publication, v. 218, pp. 1-8.

Dilek, Y. and Furnes, H., 2011, Ophiolite genesis and global tectonics: Geochemical and tectonic fingerprinting of ancient oceanic lithosphere: Geological Society of America Bulletin, v. 123, pp. 387-411.

Dilek, Y. and Furnes, H., 2014, Ophiolites and their origins: Elements, v. 10, pp. 93-100.

Dubinska, E., Bylina, P., Kozlowski, A., Dörr, W., Nejbert, K. 2004. U-Pb dating of serpentinization: Hydrothermal zircon from a metasomatic rodingite shell (Sudetic ophiolite, SW Poland). Chemical Geology, v. 203, pp. 183-203.

Faryad, S.W. and Kachlík, V., 2013, New evidence of blueschist facies rocks and their geotectonic implication for Variscan suture (s) in the Bohemian Massif: Journal of metamorphic Geology, v. 31, pp. 63-82.

Fernández-Suárez, J., Díaz García, F., Jeffries, T.E., Arenas, R. and Abati, J., 2003, Constraints on the provenance of the uppermost allochthonous terrane of the NW Iberian Massif: Inferences from detrital zircon $\mathrm{U}-\mathrm{Pb}$ ages: Terra Nova, v. 15, pp. 138-144.

Fernández-Suárez, J., Arenas, R., Abati, J., Martínez Catalán, J.R., Whitehouse, M.J. and Jeffries, T.E., 2007, U-Pb chronometry of polymetamorphic high-pressure granulites: An example from the allochthonous terranes of the NW Iberian Variscan belt, in Hatcher, R.D. Jr., Carlson, M.P., McBride, J.H. and Martínez Catalán, J.R., eds, 4-D Framework of Continental Crust: Geological Society of America Memoir, v. 200, pp. 469-488.

Fuenlabrada, J.M., Arenas, R., Sánchez Martínez, S., Díaz García, F. and Castiñeiras, P., 2010, A peri-Gondwana arc in NW Iberia. I: Isotopic and geochemical constraints on the origin of the arc-A sedimentary approach: Gondwana Research, v. 17, pp. 338-351.

Fuenlabrada, J.M., Arenas, R., Díez Fernández, R., Sánchez Martínez, S., Abati, J. and López Carmona, A., 2012, Sm-Nd isotope geochemistry and tectonic setting of the metasedimentary rocks from the basal allochthonous units of NW Iberia (Variscan suture, Galicia): Lithos, v. 148 , pp. 196-208.

García-Casco, A., Iturralde-Vinent, M.A. and Pindell, J., 2008, Latest Cretaceous collision/accretion between the Caribbean plate and Caribeana: Origin of metamorphic terranes in the Greater Antilles: International Geology Review, v. 50, pp. 781-809.

Gerya, T.V., Stöckhert, B. and Perchuk, A.L., 2002, Exhumation of highpressure metamorphic rocks in a subduction channel: A numerical simulation: Tectonics, v. 21, pp. 6-1-19.

Gómez-Barreiro, J., Martínez Catalán, J.R., Arenas, R., Castiñeiras, P., Abati, J., Díaz García, F. and Wijbrans, J.R., 2007, Tectonic evolution of the upper allochthon of the Órdenes complex (northwestern Iberian Massif): Structural constraints to a polyorogenic peri-Gondwanan terrane, in Linneman, U., Nance, R.D., Kraft, P. and Zulauf, G., eds, The evolution of the Rheic Ocean: From Avalonian-Cadomian active margin to Alleghenian-Variscan collision: Geological Society of America Special Paper, v. 423, pp. 315-332.

Gómez Barreiro, J., Martínez Catalán, J.R., Prior, D., Wenk, H.-R., Vogel, S., Díaz García, F., Arenas, R., Sánchez Martínez, S. and Lonardelli, I., 2010, Fabric development in a Middle Devonian intra-oceanic subduction regime: the Careón ophiolite (NW Spain): Journal of Geology, v. 118, pp. 163-186

Hebert, L.B., Antoshechkina, P., Asimow, P and Gurnis, M., 2009, Emergence of a low-viscosity channel in subduction zones through the coupling of mantle flow and thermodynamics: Earth and Planetary Science Letters, v. 278, pp. 243-256.

Kroner, U. and Romer, R.L., 2013, Two plates-Many subduction zones: The Variscan orogeny reconsidered: Gondwana Research, v. 24, pp. 298-329. 
Kryza, R. and Pin, C., 2010, The Central-Sudetic ophiolites (SW Poland): Petrogenetic issues, geochronology and palaeotectonic implications: Gondwana Research, v. 17, pp. 292-305.

Lardeaux, J.M., Ledru, P., Daniel, I. and Duchene, S., 2001, The Variscan French Massif Central-a new addition to the ultra-high pressure metamorphic 'club': exhumation processes and geodynamic consequences: Tectonophysics, v. 332, pp. 143-167.

Le Moigne, J., Lagabrielle, Y., Whitechurch, H., Girardeau, J., Bourgois, J. and Maury, R.C., 1996, Petrology and geochemistry of the ophiolitic and volcanic suites of the Taitao Peninsula-Chile Triple Junction Area: Journal of South American Earth Sciences, v. 9, pp. 43-58.

Leitch, E.C., 1984, Island arc elements and arc-related ophiolites: Tectonophysics, v. 106, pp. 177-203.

López Carmona, A., Pitra, P. and Abati, J., 2013, Blueschist-facies metapelites from the Malpica-Tui Unit (NW Iberian Massif): phase equilibria modelling and $\mathrm{H}_{2} \mathrm{O}$ and $\mathrm{Fe}_{2} \mathrm{O}_{3}$ influence in high-pressure assemblages: Journal of Metamorphic Geology, v. 31, pp. 263-280.

López Carmona, A., Abati, J., Pitra, P., and Lee, J.K.W., 2014, Retrogressed lawsonite blueschists from the NW Iberian Massif: P-T constraints from numerical modelling and ${ }^{40} \mathrm{Ar} /{ }^{39} \mathrm{Ar}$ geochronology: Contributions to Mineralogy and Petrology, v. 167, 987, pp. 1-20.

Marcos, A., Farias, P., Galán, G., Fernández, F.J., and Llana-Fúnez, S., 2002, Tectonic framework of the Cabo Ortegal Complex: A slab of lower crust exhumed in the Variscan orogen (northwestern Iberian Peninsula), in Martínez Catalán, J.R., Hatcher, R.D. Jr., Arenas, R. and Díaz García, F., eds, Variscan-Appalachian dynamics: the building of the Late Paleozoic basement: Geological Society of America Special Paper, v. 364, pp. 143162.

Martínez Catalán, J.R., 2011, Are the oroclines of the Variscan belt related to late Variscan strike-slip tectonics? Terra Nova, v. 23, pp. 241-247.

Martínez Catalán, J.R., Arenas, R., Díaz García, F., González Cuadra, P., Gómez-Barreiro, J., Abati, J., Castiñeiras, P., Fernández-Suárez, J., Sánchez Martínez, S., Andonaegui, P., González Clavijo, E., Díez Montes, A., Rubio Pascual, F.J. and Valle Aguado, B., 2007, Space and time in the tectonic evolution of the northwestern Iberian Massif: Implications for the Variscan belt, in Hatcher, R.D. Jr., Carlson, M.P., McBride, J.H. and Martínez Catalán, J.R., eds, 4-D Framework of Continental Crust: Geological Society of America Memoir, v. 200, pp. 403-423.

Martínez Catalán, J.R., Arenas, R., Abati, J., Sánchez Martínez, S., Díaz García, F., Fernández-Suárez, J., González Cuadra, P., Castiñeiras, P., Gómez Barreiro, J., Díez Montes, A., González Clavijo, E., Rubio Pascual, F.J., Andonaegui, P., Jeffries, T.E., Alcock, J.E., Díez Fernández, R. and López Carmona, A., 2009, A rootless suture and the loss of the roots of a mountain chain: The Variscan belt of NW Iberia: Comptes Rendus Geoscience, v. 341, pp. 114-126.

Matte, Ph., 2001, The Variscan collage and orogeny (480-290 Ma) and the tectonic definition of the Armorica microplate: a review: Terra Nova, v. 13 , pp. 122-128

Murphy, J.B., Gutiérrez-Alonso, G., Nance, R.D., Fernández-Suárez, J., Keppie, J.D., Quesada, C., Strachan, R.A. and Dostal, J., 2006, Origin of the Rheic Ocean: rifting along a Neoproterozoic suture?: Geology, v. 34, pp. 325-328

Murphy, J.B., Gutiérrez-Alonsi, G., 2008, The origin of the Variscan upper allochthons in the Ortegal Complex, northwestern Iberia: Sm-Nd isotopic constraints on the closure of the Rheic Ocean. Canadian Journal of Earth Sciences, v. 45, pp. 651-668.

Murphy, J.B., Cousens, B.L., Braid, J.A., Strachan, R.A., Dostal, J., Keppie, J.D. and Nance, R.D., 2011, Highly depleted oceanic lithosphere in the Rheic Ocean: Implications for Paleozoic plate reconstructions: Lithos, v. 123, pp.165-175.

Nance, R.D., Gutiérrez-Alonso, G., Keppie, J.D., Linnemann, U., Murphy, J.B., Quesada, C., Strachan, R.A. and Woodcock, N.H., 2010, Evolution of the Rheic Ocean: Gondwana Research, v, 17, pp. 194-222.

Nicolas, A., 1989, Structures of ophiolites and dynamics of oceanic lithosphere: Kluwer Academic Publishers, 367 p.
Nicolas, A., 1995, The mid-oceanic ridges. Mountains below sea level: Springer-Verlag. 200 p.

Nutman, A.P., Green, D.H., Cook, C.A., Styles, M.T. and Holdsworth, R.E., 2001, SHRIMP U-Pb zircon dating of the exhumation of the Lizard Peridotite and its emplacement over crustal rocks: Constraints for tectonic models: Journal of the Geological Society, London, v. 158, pp. 809-820.

Ordóñez Casado, B., Gebauer, D., Schäfer, H.J., Gil Ibarguchi, J.I. and Peucat, J.J., 2001, A single Devonian subduction event for the HP/HT metamorphism of the Cabo Ortegal complex within the Iberian Massif: Tectonophysics, v. 332, pp. 359-385.

Pearce, J.A., 1996, A users guide to basalt discrimination diagrams, in Wyman, D.A., ed, Trace Element Geochemistry of Volcanic Rocks: Application for Massive Sulphide Exploration: Short Course Notes, Geological Association of Canada, v. 12, pp. 79-113.

Pearce, J.A., 2014, Immobile element fingerprinting of ophiolites: Elements, v. 10 , pp. 101-108

Pearce, J.A., Lippard, S.J. and Roberts, S., 1984, Characteristics and tectonic significance of supra-subduction zone ophiolites, in Kokelaar, B.P. and Howells, M.F., eds, Marginal Basin Geology: Geological Society, London, Special Publications, v. 16, pp. 77-94.

Pin, C., Paquette, J.L., Santos Zalduegui, J.F. and Gil Ibarguchi, J.I., 2002, Early Devonian supra-subduction zone ophiolite related to incipient collisional processes in the Western Variscan Belt: The Sierra de Careón unit, Órdenes Complex, Galicia, in Martínez Catalán, J.R., Hatcher, R.D. Jr., Arenas, R. and Díaz García, F., eds, Variscan-Appalachian dynamics: the building of the Late Paleozoic basement.: Geological Society of America Special Paper, v. 364, pp. 57-71.

Pin, C., Paquette, J.L., Ábalos, B., Santos, J.F. and Gil Ibarguchi, J.I., 2006, Composite origin of an early Variscan transported suture: Ophiolitic units of the Morais Nappe Complex (north Portugal): Tectonics, v. 25, pp. 1-19.

Pin, C., Paquette, J.L., Santos Zalduegui, J.F. and Gil Ibarguchi, J.I., 2002, Early Devonian supra-subduction zone ophiolite related to incipient collisional processes in the Western Variscan Belt: The Sierra de Careón unit, Órdenes Complex, Galicia, in Martínez Catalán, J.R., Hatcher, R.D. Jr., Arenas, R. and Díaz García, F., eds, Variscan-Appalachian Dynamics: the building of the Late Paleozoic Basement: Geological Society of America Special Paper, v. 364, pp. 57-71.

Pin, C., Paquette, J.L., Ábalos, B., Santos, J.F. and Gil Ibarguchi, J.I., 2006, Composite origin of an early Variscan transported suture: Ophiolitic units of the Morais Nappe Complex (north Portugal): Tectonics, v. 25, pp. 1-19.

Platt, J.P., 1986, Dynamic of orogenic wedges and the uplift of high-pressure metamorphic rocks: Geological Society of America Bulletin, v. 97, pp. 1037-1053.

Rodríguez, J., Cosca, M.A., Gil Ibarguchi, J.I. and Dallmeyer, R.D., 2003, Strain partitioning and preservation of ${ }^{40} \mathrm{Ar} /{ }^{39} \mathrm{Ar}$ ages during Variscan exhumation of a subducted crust (Malpica-Tui complex, NW Spain): Lithos, v. 70, pp. 111-139.

Saccani, E., Dilek, Y., Marroni, M., and Pandolfi, L., 2015, Continental margin ophiolites of Neotethys: Remnants of ancient Ocean-Continent Transition Zone (OCTZ) lithosphere and their geochemistry, mantle sources and melt evolution patterns. Episodes, v. 38, no. 4, pp.230-249, doi:10.18814/ epiiugs/2015/v38i4/82418.

Sánchez Martínez, S., 2009, Geoquímica y geocronología de las ofiolitas de Galicia: Nova Terra, v. 37, 351 p.

Sánchez Martínez, S., Jeffries, T., Arenas, R., Fernández-Suárez, J. and García-Sánchez, R., 2006, A pre-Rodinian ophiolite involved in the Variscan suture of Galicia (Cabo Ortegal Complex, NW Spain): Journal of the Geological Society, London, v. 163, pp. 737-740.

Sánchez Martínez, S., Arenas, R., Díaz García, F., Martínez Catalán, J.R., Gómez Barreiro, J. and Pearce, J., 2007a, The Careón Ophiolite, NW Spain: supra-subduction zone setting for the youngest Rheic Ocean floor: Geology, v. 35, pp. 53-56.

Sánchez Martínez, S., Arenas, R., Andonaegui, P., Martínez Catalán, J.R. and Pearce, J.A., 2007b, Geochemistry of two associated ophiolites from 
the Cabo Ortegal Complex (Variscan belt of northwest Spain), in Hatcher, R.D. Jr., Carlson, M.P., McBride, J.H. and Martínez Catalán, J.R., eds, 4-D Framework of Continental Crust: Geological Society of America Memoir, v. 200, pp. 445-467.

Sánchez Martínez, S., Arenas, R., Fernández-Suárez, J. and Jeffries, T.E., 2009, From Rodinia to Pangaea: ophiolites from NW Iberia as witness for a long-lived continental margin, in Murphy, J.B., Keppie, J.D. and Hynes, A.J., eds, Ancient Orogens and Modern Analogues: Geological Society, London, Special Publications, v. 327, pp. 317341.

Sánchez Martínez, S., Arenas, R., Gerdes, A., Castiñeiras, P., Potrel, A. and Fernández-Suárez, J., 2011, Isotope geochemistry and revised geochronology of the Purrido Ophiolite (Cabo Ortegal Complex, NW Iberian Massif): Devonian magmatism with mixed sources and involved Mesoproterozoic basement: Journal of the Geological Society, London, v. 168 , pp. $733-750$.

Sánchez Martínez, S., Gerdes, A., Arenas, R. and Abati, J., 2012, The Bazar Ophiolite of NW Iberia: a relic of the Iapetus-Tornquist Ocean in the Variscan suture: Terra Nova, v. 24, pp. 283-294.

Sánchez Martínez, S., Arenas, R., Albert, R., Gerdes, A. and Potrel, A., 2013, Detailed re-dating of the Vila de Cruces Ophiolite (allochthonous complexes of NW Iberia): The opening of a back-arc basin in the Gondwana shelf, in •ák, J., Zulauf, G. and Röhling, H.-G., eds, Crustal evolution and geodynamic processes in Central Europe (abs): Proceedings of the Joint conference of the Czech and German geological societies, Pilsen, Czech Republic, v. 82, pp. 95.

Shin, K.-C., Anma, R., Nakano, T., Orihashi, Y., and Ike, S.-I., 2015, TheTaitao ophiolite-granite complex, Chile: Emplacement of ridge-trench intersection oceanic lithosphere on land and origin of calc-alkaline Itype granites. Episodes, v. 38, no. 4, pp. 283-297, doi: 10.18814/epiiugs/ 2015/v38i4/82424.

Sommer, M., Hüneke, H., Meschede, M. and Cobiella-Reguera, J., 2011, Geodynamic model of the northwestern Caribbean: scaled reconstruction of Late Cretaceous to Late Eocene plate boundary relocation in Cuba:
Neues Jahrbuch für Geologie und Paläontologie, Monatschefte, v. 259, pp. 299-312.

Stampfli, G.M. and Borel, G.D., 2002, A plate tectonic model for the Paleozoic and Mesozoic constrained by dynamic plate boundaries and restored synthetic oceanic isochrones: Earth and Planetary Science Letters, v. 196, pp. 17-33.

Van Staal, C.R., Barr, S.M. and Murphy, J.B., 2012. Provenance and tectonic evolution of Ganderia: Constraints on the evolution of the Iapetus and Rheic oceans: Geology, v. 40, pp. 987-990.

Vervoort, J.D. and Blichert-Toft, J., 1999, Evolution of the depleted mantle: $\mathrm{Hf}$ isotope evidence from juvenile rocks through time: Geochimica et Cosmochimica Acta, v. 63, pp. 533-556.

Von Raumer, J.F., Stampfli, G.M., Arenas, R. and Sánchez Martínez, S., 2015, Ediacaran to Cambrian oceanic rocks of the Gondwana margin and their tectonic interpretation: International Journal of Earth Sciences, v. 104, pp. 1107-1121. DOI 10.1007/s00531-015-1142-x

Warren, C.J., Beaumont, C. and Jamieson, R.A., 2008, Modelling tectonic styles and ultra-high pressure (UHP) rock exhumation during the transition from oceanic subduction to continental collision: Earth and Planetary Science Letters, v. 267, pp. 129-145.

Winchester, J.A., Pharaoh, T.C. and Verniers, J., 2002, Palaeozoic amalgamation of Central Europe: an introduction and synthesis of new results from recent geological and geophysical investigations, in Winchester, J.A., Pharaoh, T.C. and Verniers, J., eds, Palaeozoic Amalgamation of Central Europe: Geological Society, London, Special Publications, v. 201, pp. 1-18.

Wood, D.A., 1980, The application of a Th-Hf-Ta diagram to problems of tectomagmatic classification and to establishing the nature of crustal contamination of basaltic lavas of the British Tertiary Volcanic Province: Earth and Planetary Science Letters, v. 50, pp. 11-30.

Yang, G.X. and Dilek, Y., 2015, OIB- and P-Type ophiolites along the YarlungZangbo Suture Zone (YZSZ), Southern Tibet: Poly-phase melt history and mantle sources of the Neotethyan oceanic lithosphere. Episodes, v. 38 , no. 4 , pp. $250-265$, DOI: $10.18814 /$ epiiugs/2015/v38i4/82420. 